Article

\title{
First Comprehensive Quantitative Multi-Parameter Assessment of the Eutrophication Status from Coastal to Marine French Waters in the English Channel, the Celtic Sea, the Bay of Biscay, and the Mediterranean Sea
}

\author{
Alain Lefebvre* *D and David Devreker \\ IFREMER (French Research Institute for Exploitation of the Sea), Laboratoire Environnement Ressources, \\ 62321 Boulogne-sur-Mer, France; David.Devreker@ifremer.fr \\ * Correspondence: alain.lefebvre@ifremer.fr
}

Received: 12 June 2020; Accepted: 23 July 2020; Published: 25 July 2020

\begin{abstract}
The first quantitative and comprehensive assessment of the eutrophication status from coastal to offshore French waters was performed within the Marine Strategy Framework Directive (MSFD descriptor 5) for the English Channel, the southern bight of the North Sea, the Celtic Seas, the Bay of Biscay and the Western Mediterranean Sea. Based on a combination of different data sources (in situ, satellite, and modeling products), a fully-integrated dataset was generated over the period 2010-2016. Using the best available knowledge on the eutrophication process and definition, the assessment procedure was implemented considering nutrient pressures, and direct and indirect effects of excessive inputs. The different steps of the assessment were: (i) Establishment of assessment levels and thresholds, (ii) development of methodology for aggregation and integration of data, and (iii) qualification of the Environmental Status. We investigated how reliable this assessment procedure was when considering other complementary information. Results highlighted that, despite efforts in recent decades to reduced nutrient inputs, the pressure on coastal marine ecosystems was still high. We discuss options for improving the coherence between MSFD and other similar approaches and associated monitoring programs. This study identifies areas where an increased monitoring effort is needed to improve the assessment and where environmental management actions are of priority.
\end{abstract}

Keywords: eutrophication; assessment; Marine Strategy Framework Directive (MSFD); Water Framework Directive (WFD); Oslo and Paris Convention (OSPAR); English Channel; Celtic Seas; Bay of Biscay; Mediterranean Sea; nutrients; chlorophyll; oxygen; turbidity; phytoplankton; macro-algae

\section{Introduction}

Eutrophication was recently referred to as "a new wine in an old bottle" in the context of a new wave of eutrophication issues linked to diffuse nitrogen and phosphorus pollution, with consequences similar to the historic ones (i.e., the "old bottle") and because this diffuse context forces new processes to be addressed (i.e., the "new wine") [1]. Therefore, the new definition of anthropogenic eutrophication was expressed as "an aquatic ecosystem syndrome (i.e., set of symptoms representative of the multitude of biogeochemical and biological responses generated by nutrient inputs) associated with the overproduction of organic matter induced by anthropogenic inputs of phosphorus and nitrogen" [1]. Eutrophication is one of the most extended and investigated processes, but whereas qualitative interactions between elements involved in the eutrophication process are considered to 
be well-known [2], the quantification of these interactions remains poorly informed, and is generally done only by considering a limited number of parameters and interactions. Eutrophication studies are driven by the background knowledge of the expert who coordinate the research project (i.e., biology, biogeochemistry, benthic, or pelagic compartments), or by current concerns (e.g., biodiversity, climatic change) leading to shortcuts in prioritized research areas or in methodological assessment development. In areas where eutrophication is a problem or a potential problem, there is a requirement for regular assessments, including quantification of nutrient budgets and concentrations, and direct and indirect effects of nutrient discharges. These assessments are of primary importance for environmental management purposes.

In the European Union (EU), environmental directives exist for community action in the field of environmental and water policies. These include the Nitrates Directive [3], the Urban Wastewater Treatment Directive [4], the Water Framework Directive (WFD) [5], and more recently, the Marine Strategy Framework Directive (MSFD) [6]. Eutrophication is also addressed by Regional Sea Conventions (RSC) such as the Oslo and Paris Convention for the Protection of the Northeast Atlantic (OSPAR) [7], the Helsinki Convention (HELCOM, 2007) for the Protection of the Baltic Sea [2,8], and the Barcelona convention (MEDPOL) for the Mediterranean Sea [9], although they have only limited enforcement powers, if any. Whilst each directive or process is different in terms of scope, assessment areas, and integration rules, there is a set of common indicators across all assessment procedures: Nutrients, phytoplankton biomass (chlorophyll-a), oxygen concentration. Other indicators linked to water transparency, microalgae, Harmful Algal Blooms (HAB), macrophytes, and macrofaunal communities of benthic habitats are also considered.

For EU marine waters, the MSFD established a community framework in which member states must act to reduce the impacts of human activities on marine ecosystems so as to maintain or reach a Good Environmental Status (GES). The directive has been transposed into French legislation. For each marine sub-region, a Marine Action Plan was developed and implemented. This action plan comprises 5 elements: An initial assessment, determination of a set of characteristics for GES status, establishment of environmental targets and associated indicators, a monitoring program, and a program of measures. This marine action plan must be renewed every 6 years. MSFD is now at the end of its second cycle of implementation. At the European scale, marine action plans, developed by member states and spatially delimited by their Exclusive Economic Zone (EEZ, from baseline to $200 \mathrm{~nm}$ ), must be coherent with each other across marine regions and sub-regions, and in which different regional and European sea conventions and directives apply.

The definition of GES and the means to reach it are described by eleven descriptors, delivering an ecosystemic (holistic functional) approach of the problem. This MSFD approach is more integrative than the WFD. Borja et al. [10] characterized the WFD as a "deconstructing structural approach" in which "there is no holistic eutrophication assessment model that takes into account pelagic and benthic components, since the WFD evaluates subsets of these as individual quality elements". The eleven MSFD descriptors are divided into 42 primary (that must be assessed in every situation) and secondary (that must be assessed when pertinent) criteria. Among these descriptors, MSFD descriptor 5-eutrophication (defined by 8 criteria, see below in section "Criteria/indicators for eutrophication assessment" for details) requires that "Human-induced eutrophication is minimized, especially adverse effects thereof, such as losses in biodiversity, ecosystem degradation, harmful algal blooms, and oxygen deficiency in bottom waters". The challenge is to reduce complex information on eutrophication issues to conclude if the assessed areas reach GES or not.

Under previous WFD coastal assessments, but also under OSPAR assessments (which should include all water masses under sovereignty and jurisdiction of member states), determination of the French eutrophication status was only based on a 1 nautical mile (nm) narrow coastal area, and showed issues related to eutrophication processes, such as opportunistic macroalgae blooms in Brittany and high levels of phytoplanktonic biomass (i.e., chlorophyll- $a$ concentration) in the Eastern English Channel. The existence of vulnerable areas to nitrate inputs, as identified under the Nitrates 
Directive and sensitive areas as shaped under the Urban Wastewater Treatment directive, lead to the identification of eutrophication problems areas in other French coastal waters. However, the assessment of a eutrophication status for French waters, i.e., beyond the 1 nautical mile baseline, is still missing. Even within the last OSPAR assessment in 2016 (including all French marine waters of the English Channel, the Celtic Seas, and Atlantic), the assessment was restrained to WFD's $1 \mathrm{~nm}$ coastal waters due to a lack of methodologies and/or offshore data. Consequently, offshore assessments were made by expert judgment, and all waters beyond $1 \mathrm{~nm}$ were considered as non-problem or potential problem areas with regard to the eutrophication status. The working hypothesis was that eutrophication was only critical in proximate coastal waters.

Various methods have been proposed by OSPAR and MSFD working groups to assess eutrophication. Most of the time, these methods are based on studies for territorial waters or a part thereof (i.e., with a specific set of pressures, impacts leading to specific environmental conditions which cannot be generalized) with a given monitoring program (being well-suited to local environmental conditions). Consequently, when considering a whole marine region shared by numerous member states, many assessment outcomes appear inconsistent, discontinuous when dealing with neighboring countries. This situation is detrimental when environmental management action plans are to be developed. Indeed, given scientific inconsistency or uncertainty, this created an opportunity for some stakeholders or the society at large not to take action against eutrophication. Furthermore, too many working groups have been created, leading to an even greater amount of information, almost impossible to synthesize.

The purpose of this study was to share with the scientific community and with environmental managers the French MSFD Eutrophication Assessment Procedure as an example of a purely numerical procedure, followed by an expert-based revision that accurately represents the eutrophication status at the French EEZ scale. Our study reports the first quantitative assessment of the eutrophication status in the English Channel, the Celtic Seas, the Bay of Biscay and the Western Mediterranean Sea for the whole French EEZ over the period 2010-2016 using a combination of in situ, remote sensing, and modeling data to generate a fully-integrated dataset. We investigated how reliable this MSFD Eutrophication assessment procedure was, when considering other complementary information (published or gray data, expert judgments). We also opened the discussion for new perspectives focusing on how to improve WFD/MSFD/OSPAR coherence. Indeed, this study should help to identify areas where an increased monitoring effort is needed to improve the assessment and where environmental management actions are useful, if not a priority. This study should contribute to advance knowledge on eutrophication at the regional and trans-national boundary scales and to strategic river basin management plans.

\section{Materials and Methods}

\subsection{Assessment Areas}

French marine waters $\left(371,048 \mathrm{~km}^{2}\right)$ are part of the North East Atlantic Ocean and of the Mediterranean Sea ecoregions characterized by MSFD. To take into account ecological differences within areas, but also to allow environmental managers carrying out appropriate and coordinated measures from regional to local scales, French marine waters were sub-divided into four sub-marine regions (SMR): The English Channel and the southern bight of the North Sea (ECNS) $\left(28,348 \mathrm{~km}^{2}\right)$, the Celtic Seas (CS) $\left(43,464 \mathrm{~km}^{2}\right)$, the Bay of Biscay (BB) $\left(188,124 \mathrm{~km}^{2}\right)$, and the Western Mediterranean Sea (WMS) $\left(111,050 \mathrm{~km}^{2}\right)$ (Figure 1). The main objectives of MSFD are to analyze the characteristics and environmental status of these waters within a DPSIR frame [6,11], following the ecosystem-based approach. 


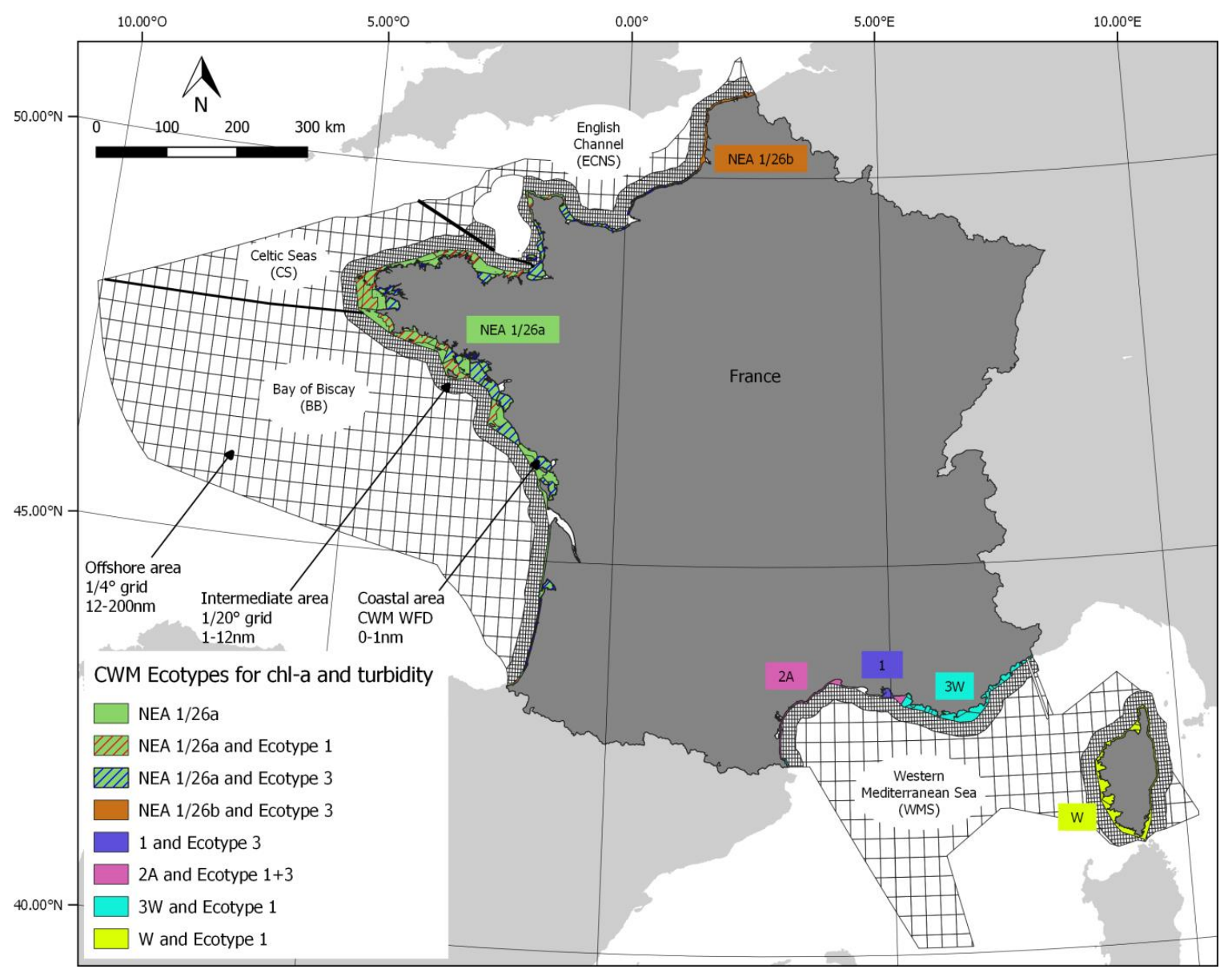

Figure 1. The French Marine Strategy Framework Directive (MSFD) Marine Regions and their corresponding Reporting Marine Units (RMU) and Geographical Assessment Units (GAU): Coastal area $(0-1 \mathrm{~nm})$, intermediate area (1-12 nm), and offshore marine area (12-200 nm). The Water Framework Directive (WFD) ecotypes for coastal marine water (CWM) are highlighted for each RMU.

Existing OSPAR and WFD assessments for France deal with coastal water bodies and estuaries. Considering the WFD seaward limit definition as "a distance of one nautical mile on the seaward side from the nearest point of the baseline from which the breadth of terrestrial waters is measured", most coastal assessment areas miss the largest part of offshore eutrophic river plumes. Indeed, even if nutrient inputs are high in some areas, turbidity is often too high to allow aquatic plant growth. Nevertheless, productive phytoplankton communities with high biomass concentration may increase in offshore nutrient-enriched waters, where turbidity is lower, leading to direct and indirect effects. In addition, the aim of our methodological approach was to include considerations of both environmental characteristics and the human dimension so as to divide a large water body into suitable managements units, and then SMR are split into sub-areas: Coastal waters up to $1 \mathrm{~nm}$, intermediate waters from 1 to $12 \mathrm{~nm}$, and offshore waters beyond $12 \mathrm{~nm}$ (Figure 1). These sub-areas correspond to Reporting Marine Units (RMUs), i.e., the smallest assessment areas available for the European Commission reporting processes.

In France, these different RMUs are then divided into Geographical Assessment Units (GAU); these are the smallest geographical units in which the indicators have to be calculated. In the coastal areas, GAU are WFD water masses (without transitional waters), in accordance with Commission Decision 2017/848. There are 24 GAU for ECNS, 15 for CS, 34 for BB, and 46 for WMS (Figure 1).

In the intermediate water masses, geographical assessment units are $1 / 20^{\circ}$ (approximately, $20 \mathrm{~km}^{2}$ )-width cell size, whereas offshore waters are divided into $1 / 4^{\circ}$ (approximately, $500 \mathrm{~km}^{2}$ )-width 
cell size (Figure 1). This breakdown using a gridded approach takes into account the decreasing gradient of eutrophication importance from coastal to marine waters.

\subsection{Criteria/Indicators for Eutrophication Assessment}

The eight criteria defining MSFD descriptor 5 are: (D5C1) nutrients in the water column (primary criteria), (D5C2) chlorophyll- $a$ (chl-a) in the water column (primary criterion), (D5C3) harmful algal blooms in the water column (secondary criterion), (D5C4) photic limit (transparency) of the water column (secondary criterion), (D5C5) dissolved oxygen in the bottom of the water column (primary criterion), (D5C6) opportunistic macroalgae of benthic habitats (secondary criterion), (D5C7) macrophyte communities of benthic habitats (secondary criterion), and (D5C8) macrofaunal communities of benthic habitats (secondary criterion). According to the MSFD guidelines, "Primary criteria should be used to ensure consistency across the Union, flexibility should be granted with regard to secondary criteria. The use of a secondary criterion should be decided by Member States, where necessary, to complement a primary criterion or when, for a particular criterion, the marine environment is at risk of not achieving or not maintaining good environmental status". Each criterion was linked to one or more indicators. Indicators of the same criteria, and criteria among them, have to be integrated at a regional scale to assess descriptor 5. Main characteristics of each dataset and relative criterion are summarized in Tables 1 and 2. For turbidity, WFD ecotypes 1 and 3 are, respectively, rocky areas and Mediterranean coast, and sandy and muddy areas and mouths of the main rivers. An ecotype is the reference to which a water body is attached during the ecological assessment. For chlorophyll- $a$, North East Atlantic (NEA) WFD ecotypes 1/26a and 1/26b correspond to the Eastern English Channel, and Western English Channel-Celtic Seas-Bay of Biscay, respectively.

Table 1. Surface area of each Reporting Marine Unit (RMU, in $\mathrm{km}^{2}$ ) (coastal marine water (CMW), intermediate (Inter.), and offshore waters) and number of data points used to assess each criterion (D5C1 Nutrients, D5C2 Chlorophyll- $a$ (Chl-a), D5C4 Turbidity, and D5C5 Oxygen) in the different French assessment areas: Southern bight of the North Sea (ECNS), the Celtic Seas (CS), the Bay of Biscay (BB), and the Western Mediterranean Sea (WMS).

\begin{tabular}{ccccccc}
\hline \multirow{2}{*}{ Marine Regions } & RMU & Area $\mathbf{( k m}^{\mathbf{2}}$ ) & Nutrients & Chl-a & Turbidity & Oxygen \\
\hline \multirow{3}{*}{ ECNS } & CMW & 2417 & 382 & 934 & 886 & 304 \\
& Inter. & 11,886 & 453,306 & $16,934,060$ & $16,924,128$ & 459,330 \\
& Offshore & 14,045 & 534,576 & $20,045,685$ & $20,033,928$ & 541,680 \\
\hline \multirow{2}{*}{ CS } & CMW & 4,873 & 225 & 428 & 473 & 85 \\
& Inter. & 6705 & 250,432 & $9,321,235$ & $9,315,768$ & 253,760 \\
& Offshore & 31,886 & $1,031,828$ & $44,272,030$ & $44,246,064$ & $1,045,540$ \\
\hline \multirow{2}{*}{ BB } & CMW & 8132 & 469 & 948 & 953 & 332 \\
& Inter. & 14,135 & 506,282 & $19,031,210$ & $19,020,048$ & 513,010 \\
& Offshore & 165,857 & $4,899,678$ & $220,713,955$ & $220,584,504$ & $4,964,790$ \\
\hline \multirow{2}{*}{ WMS } & CMW & 4631 & NA & 741 & 655 & 3 \\
& Inter. & 19,757 & 33,300 & $36,810,735$ & $24,743,784$ & 33,300 \\
& Offshore & 86,668 & 150,780 & $165,758,580$ & $111,421,152$ & 150,780 \\
\hline
\end{tabular}

\subsection{Datasets}

For coastal areas, data related to criteria D5C1 to D5C5 mainly came from the well-established Phytoplankton Monitoring Program [12,13] (Table 1). Data for the benthic compartment (D5C6, D5C7) came from the WFD-specific monitoring program [14,15]. All of these data were considered as conventional (based on standardized practices for in situ sampling then analysis), and as low spatial and temporal resolution data.

In intermediate and offshore areas, conventional in situ and low-resolution data were too scarce to provide an assessment result for each geographical assessment unit. Consequently, spatially gridded 
(1.2 km resolution), monthly averaged (from daily images) chlorophyll- $a$ (Chl- $a$ ) concentrations and turbidity were derived from the merging of SeaWiFS, MERIS, MODIS/AQUA, and VIIRS remote-sensing reflectance, processed by the coastal OC5 algorithm with Look-Up-Tables dedicated to each sensor [16,17] (Table 1). The OC5 algorithm was specifically designed for waters where suspended sediment may hamper the application of the classical OCx algorithms as used for the open ocean $[18,19]$.

Data for nutrients and bottom-dissolved oxygen concentration were provided by hydrodynamicalbiogeochemical models: ECOMARS-3D (16 km resolution; daily dataset; 2012-2016 period) for the ECNS, CS and BB marine regions [20], and 3DVAR-OGSTM-BFM/Med-Currents [21] (36 km resolution; monthly dataset; 2010-2014 period) for the WMS marine region (Table 2).

\subsection{Data Quality, Quantity, and Confidence}

In situ coastal data were subject to a validation and qualification procedure [22] as applied for the WFD assessment. Only data with a quality control flag "good" (all QC test passed) were used. Validation of satellite- and modeling- derived products were done using classical methodologies (comparison between satellite products and in situ datasets using specific statistics as relative bias, correlation coefficients, Relative Standard Deviation, Root Mean Square Error, Taylor Diagrams) [17].

Table 2. Characteristics of the data, metrics, and indicators used for the assessment of descriptor 5 eutrophication (2A: Primary Criteria; 2B: Secondary Criteria) in the different Reporting Marine Units (RMU) (CA: Coastal area, IA: Intermediate area, OA: Offshore marine area) and French sub-marine regions (The English Channel and the southern bight of the North Sea (ECNS), the Celtic Seas (CS), the Bay of Biscay (BB), and the Western Mediterranean Sea (WMS)). ECNS, CS, and BB sub-marine regions (SMRs) together correspond to the Atlantic Area (Atl.) (na: Not assessed; DIN33: Nutrient concentration normalized for salinity 33 to compensate for differences at the various locations and during the various years).

\begin{tabular}{|c|c|c|c|c|}
\hline \multirow{2}{*}{$\begin{array}{c}\text { Criteria } \\
\text { Indicators }\end{array}$} & \multicolumn{2}{|c|}{$\begin{array}{l}\text { D5C1 } \\
\text { Nutrients in the Water Column }\end{array}$} & \multirow{2}{*}{$\begin{array}{l}\text { D5C2 } \\
\begin{array}{c}\text { Chlorophyll- } a \text { in the } \\
\text { Water Column }\end{array} \\
\text { [Chlorophyll- } a]\end{array}$} & \multirow{2}{*}{$\begin{array}{c}\text { D5C5 } \\
\begin{array}{c}\text { Dissolved Oxygen in the Bottom } \\
\text { of the Water Column }\end{array} \\
\text { [Oxygen] } \\
\end{array}$} \\
\hline & [DIN] & [DIP] & & \\
\hline $\begin{array}{l}\text { Elements Used } \\
\text { (Parameters) }\end{array}$ & $\begin{array}{l}\text { CA: surf. } \mathrm{NO}_{3}{ }^{-}, \mathrm{NO}_{2}^{-}, \mathrm{NH}_{4}{ }^{+} \\
\text {IA and } \mathrm{OA} \text { : surface } \mathrm{NO}_{3}{ }^{-}\end{array}$ & $\begin{array}{c}\text { CA: na } \\
\text { IA et OA: surface } \mathrm{PO}_{4}{ }^{3-}\end{array}$ & Surface chlorophyll- $a$ & $\begin{array}{l}\text { WMS (IA and OA): Surface oxygen } \\
\text { Others: Bottom oxygen }\end{array}$ \\
\hline RMU & All (excepted WMS CW) & IA an OA & All & All \\
\hline Marine Regions & All & All & All & All \\
\hline Assessment Years & $\begin{array}{r}\text { CA: } 2010 \\
\text { IA and OA: } 201 \\
2010-2014 \\
\end{array}$ & $\begin{array}{l}-2015 \\
-2016 \text { (Atl.) } \\
\text { (WMS) }\end{array}$ & $\begin{array}{c}\text { CA: } 2010-2015 \\
\text { IA and OA: } 2010-2016\end{array}$ & $\begin{array}{c}\text { CA: 2010-2015 } \\
\text { IA and OA: 2012-2016 (Atl.), 2010-2014 } \\
\text { (WMS) }\end{array}$ \\
\hline $\begin{array}{l}\text { Data Aquisition } \\
\text { Frequency }\end{array}$ & $\begin{array}{r}\text { CA: twice } \\
\text { IA and OA: daily (Atl.), }\end{array}$ & $\begin{array}{l}\text { month } \\
\text { honthly mean (WMS) }\end{array}$ & $\begin{array}{l}\text { CA: twice a month } \\
\text { IA and OA: daily }\end{array}$ & $\begin{array}{c}\text { CA: twice a month } \\
\text { IA and OA: daily (Att.), monthly mean } \\
\text { (WMS) }\end{array}$ \\
\hline Data Sources & $\begin{array}{r}\text { CA: RE } \\
\text { IA and OA: ECO-MA } \\
\text { 3DVAR-OGSTM-BF }\end{array}$ & $\begin{array}{l}\text { RSY } \\
\text { 2S3 model (Atl.), } \\
\text { M model (WMS) }\end{array}$ & $\begin{array}{c}\text { CA: REPHY } \\
\text { IA and OA: remote } \\
\text { sensing (MODIS-OC5Me) }\end{array}$ & $\begin{array}{c}\text { CA: REPHY } \\
\text { IA and OA: ECO-MARS3D model (Atl.), } \\
\text { 3DVAR-OGSTM-BFM model (WMS) }\end{array}$ \\
\hline $\begin{array}{l}\text { Assessment } \\
\text { Thresholds }\end{array}$ & $\begin{array}{c}\text { Atl.: } \\
\text { CA: } 29 \mu \mathrm{mol} / \mathrm{L} \\
\text { IA: } 24.65 \mu \mathrm{mol} / \mathrm{L} \\
\text { OA: } 20.03 \mu \mathrm{mol} / \mathrm{L} \\
\text { WMS: } \\
\text { IA: } 20.3 \mu \mathrm{mol} / \mathrm{L} \\
\text { OA: } 8.7 \mu \mathrm{mol} / \mathrm{L}\end{array}$ & $\begin{array}{c}\text { Atl.: } \\
\text { IA and OA: } 0.8 \mu \mathrm{mol} / \mathrm{l} \\
\text { WMS: } \\
\text { IA: } 0.56 \mu \mathrm{mol} / \mathrm{L} \\
\text { OA: } 0.24 \mu \mathrm{mol} / 1\end{array}$ & $\begin{array}{c}\text { Atl.: } \\
\text { CA NEA 1/26a: } 10 \mu \mathrm{g} \cdot \mathrm{L}-1 \\
\text { CA NEA 1/26b: } 15 \mu \mathrm{g} \cdot \mathrm{L}-1 \\
\text { IA NEA 1/26a: } 5 \mu \mathrm{g} \cdot \mathrm{L}-1 \\
\text { IA NEA 1/26b: } 7.5 \mu \mathrm{g} \cdot \mathrm{L}^{-1} \\
\text { OA NEA 1/26a: } 4 \mu \mathrm{g} \cdot \mathrm{L}^{-1} \\
\text { OA NEA 1/26b: } 6 \mu \mathrm{g} \cdot \mathrm{L}^{-1} \\
\text { WMS: } \\
\text { CA Ecotype 1: } 10 \mu \mathrm{g} \cdot \mathrm{L}^{-1} \\
\text { CA Ecotype } 2 \mathrm{~A}: 3.6 \mu \mathrm{g} \cdot \mathrm{L}^{-1} \\
\text { CA Ecotype } 3 \mathrm{~W}: 1.8 \mu \mathrm{g} \cdot \mathrm{L}^{-1} \\
\text { CA Ecotype W: } 1.22 \mu \mathrm{g} \cdot \mathrm{L}^{-1} \\
\text { IA: } 2 \mu \mathrm{g} \cdot \mathrm{L}^{-1} \\
\text { OA: } 1.44 \mu \mathrm{g} \cdot \mathrm{L}^{-1}\end{array}$ & $3 \mathrm{mg} \cdot \mathrm{L}^{-1}$ \\
\hline
\end{tabular}


Table 2. Cont.

\begin{tabular}{|c|c|c|c|c|c|c|c|}
\hline \multirow{2}{*}{$\begin{array}{l}\text { Criteria } \\
\text { Indicators }\end{array}$} & \multirow{2}{*}{$\begin{array}{c}\text { D5C4 } \\
\begin{array}{c}\text { Photic Limit (Transparency) } \\
\text { of the Water Column }\end{array} \\
\text { Turbidity }\end{array}$} & \multirow{2}{*}{$\begin{array}{c}\text { D5C6 } \\
\begin{array}{c}\text { Opportunistic Macroalgae of } \\
\text { Benthic Habitats }\end{array} \\
\text { CW-OGA } \\
\text { (WFD indicator) }\end{array}$} & \multicolumn{5}{|c|}{$\begin{array}{c}\text { D5C7 } \\
\text { Macrophyte Communities (Perennial Seaweeds and } \\
\text { Seagrasses) of Benthic Habitats }\end{array}$} \\
\hline & & & $\begin{array}{c}\mathrm{CCO} \\
\text { (WFD indicator) } \\
\end{array}$ & $\begin{array}{c}\text { QiSubMac } \\
\text { (WFD indicator) }\end{array}$ & $\begin{array}{c}\text { SBQ } \\
\text { (WFD indicator) }\end{array}$ & CARLIT (WFD indicator) & $\begin{array}{l}\text { NDSM PREI (WFD } \\
\text { indicator) }\end{array}$ \\
\hline Metrics & Percentile 90 of turbidity & EQR & EQR & EQR & EQR & $\mathrm{EQR}$ & $\mathrm{EQR}$ \\
\hline $\begin{array}{l}\text { Elements used } \\
\text { (parameters) }\end{array}$ & Surface turbidity & $\begin{array}{l}\text { Opportunistic species of genus Ulva, } \\
\text { Falkengergia, Cladophora, Enteromorpha, } \\
\text { Solieria et Pylaiella }\end{array}$ & $\begin{array}{l}\text { Perennial macroalgae } \\
\text { communities of } \\
\text { intertidal rocky shore }\end{array}$ & $\begin{array}{l}\text { Perennial macroalgae } \\
\text { communities of } \\
\text { subtial rocky shore }\end{array}$ & $\begin{array}{l}\text { Zostera marina and } \\
\text { Zostera noltei } \\
\text { eelgrass }\end{array}$ & $\begin{array}{l}\text { Perennial macroalgae } \\
\text { communities of medio- and } \\
\text { upper infralittoral shores }\end{array}$ & $\begin{array}{l}\text { Posidonia oceanica } \\
\text { eelgrass }\end{array}$ \\
\hline Metric units & NTU & no unit & no unit & no unit & no unit & no unit & no unit \\
\hline RMU & All & $\mathrm{CA}$ & $\mathrm{CA}$ & CA & $\mathrm{CA}$ & CA & CA \\
\hline Marine regions & All & ECNS, CS and BB & ECNS, CS and BB & ECNS, CS and BB & ECNS, CS and BB & WMS & WMS \\
\hline Assessment years & $\begin{array}{c}\text { CA: } 2010-2015 \\
\text { IA and OA: } 2010-2016\end{array}$ & 2010-2015 & 2010-2015 & 2010-2015 & 2010-2015 & 2010-2015 & 2010-2015 \\
\hline $\begin{array}{l}\text { Data aquisition } \\
\text { frequency }\end{array}$ & $\begin{array}{l}\text { CA: twice a month } \\
\text { IA and OA: daily }\end{array}$ & Monthly & \multicolumn{2}{|c|}{ Once every 3 years } & $\begin{array}{c}\text { once a year } \\
\text { (once avery } 6 \text { years } \\
\text { for surface survey) }\end{array}$ & Once every 6 years & Once every 3 years \\
\hline $\begin{array}{l}\text { Assessment } \\
\text { periods }\end{array}$ & March to October & May, July and September & \multicolumn{2}{|c|}{ Between March and July } & $\begin{array}{l}\text { Between August } \\
\text { and September }\end{array}$ & Between April and June & During spring \\
\hline Data sources & $\begin{array}{l}\text { CA: REPHY } \\
\text { IA and OA: remote sensing } \\
\text { (MODIS-OC5Me) }\end{array}$ & $\begin{array}{l}\text { Aerial overflights data of the CEVA } \\
\text { geo-database }\end{array}$ & \multicolumn{5}{|c|}{ «REBENT-DCE» data } \\
\hline $\begin{array}{l}\text { Assessment } \\
\text { thresholds }\end{array}$ & $\begin{array}{c}\text { Atl.: } \\
\text { CA Ecotype 1: } 10 \mathrm{NTU} \\
\text { CA Ecotype 3: } 45 \text { NTU } \\
\text { IA: 7 NTU } \\
\text { OA: 3 NTU } \\
\text { WMS: } \\
\text { CA Ecotype 1: } 10 \text { NTU } \\
\text { CA Ecotype 3: } 45 \text { NTU } \\
\text { IA: 5 NTU } \\
\text { OA: 2 NTU }\end{array}$ & 0.6 & 0.6 & 0.65 & 0.6 & 0.6 & 0.55 \\
\hline
\end{tabular}


For D5C1 (nutrients), D5C2 (Chlorophyll-a), D5C4 (turbidity), and D5C5 (oxygen), confidence was provided as a probability of belonging to a given status class. Confidence intervals and probabilities were obtained by applying the bootstrap resampling method [23], using the month as a stratifying element to take into account the seasonality of the processes involved in eutrophication.

Finally, an index was provided about the robustness of the integration process, i.e., the ratio of the number of criteria actually used for the assessment to the maximal number of relevant criteria in the considered geographical area. For intermediate and offshore marine water datasets, confidence in data quantity was not an issue, since we used mainly satellite and modeling products (no missing data). For coastal waters, confidence in the data quantity was considered as medium to good by expert-judgment, as they were extracted from optimized monitoring program devoted to WFD.

\subsection{Methodologies, Threshold and Assessment Procedure}

The main characteristics of criteria/indicators, metrics, parameters, assessment period, sampling frequencies, data sources, and assessment threshold are summarized in Tables 1 and 2.

D5C3 and D5C8 were not used for the assessment. For D5C3, we endorsed the OSPAR Commission (2008) position, considering that the link between nutrient enrichment and toxin-producing algal blooms was neither sufficiently robust nor demonstrated for all water types to be used in the eutrophication assessment, and so research was needed to justify it as an indicator of eutrophication. Moreover, the available threshold for HAB in France was based more on public health aspects than on ecological reality. D5C8 (no agreed methodology) has not been assessed, and so we used D5C5 instead, as recommended by MSFD.

For coastal areas, WFD metrics and thresholds were used (Table 2). For assessment, the One Out All Out (OOAO) principle was not used (see section below on aggregation and integration).

For Dissolved Inorganic Phosphorus, as no WFD threshold was available, pristine concentration $+50 \%$ deviation was considered as the threshold for ECNS, CS, and BB. For WMS, this threshold was applied with a reduction factor, since this ecosystem is oligotrophic.

Definition of assessment thresholds for intermediate and offshore waters was based on reduction factors applied to WFD thresholds (winter* Dissolved Inorganic Nitrogen (DIN): $29.0 \mu \mathrm{mol} \cdot \mathrm{L}^{-1}$; winter* Dissolved Inorganic Phosphorus (DIP): $0.8 \mu$ mol.L ${ }^{-1}$; Chlorophyll-a**: 10.0, 15.0, and $1.9 \mu \mathrm{g}^{*} \mathrm{~L}^{-1}$ for ecotype $1 / 26 a, 1 / 26 b$, and $2 \mathrm{~A}$, respectively; Turbidity: $10.0 \mathrm{NTU}$ ) ( ${ }^{*}$ winter defined as the period from November to February; ${ }^{* *}$ data from the productive period, i.e., from March to October) and using new data sources data from satellite and modeling products. This reduction factor was calculated as the expected reduction (in \%) of the monthly average concentration (period 2010-2016 and during the biological productive period, i.e., March to October) along coastal-offshore transects located in the different reporting marine unit.

For DIN, reduction factors (and the associated thresholds) were respectively $15 \%\left(24.7 \mu \mathrm{mol} \cdot \mathrm{L}^{-1}\right)$ and $30 \%\left(20.3 \mu \mathrm{mol} \cdot \mathrm{L}^{-1}\right)$ for intermediate and offshore ECNS, CS, BB areas. They were $30 \%$ $\left(20.3 \mu \mathrm{mol} \cdot \mathrm{L}^{-1}\right)$ and $70 \%\left(8.7 \mu \mathrm{mol} \cdot \mathrm{L}^{-1}\right)$ for intermediate and offshore WMS areas, respectively.

For DIP, pristine concentration of $0.5 \mu \mathrm{mol} \cdot \mathrm{L}^{-1}+50 \%$ deviations, i.e., a $0.8 \mu \mathrm{mol} \cdot \mathrm{L}^{-1}$ threshold, was considered for ECNS, CS, BB areas. For the WMS area, a reduction factor of $30 \%$ and $70 \%$ was applied to this threshold.

For turbidity, reduction factors (and associated threshold) were 30\% (7 NTU) and 70\% (3 NTU), respectively, for intermediate and offshore ECNS, CS, BB areas. They were 50\% (5 NTU) and 80\% (2 NTU) for the intermediate and offshore WMS area.

For oxygen, the WFD threshold of $3 \mathrm{mg} \cdot \mathrm{L}^{-1}$ was used for all areas.

For chlorophyll- $a$, application of a reduction factor of $50 \%$ to the WFD threshold for the intermediate area adjacent to ecotypes NEA $1 / 26 \mathrm{~b}$ and $1 / 26 \mathrm{a}$ resulted respectively in a threshold of 7.5 and $5 \mu \mathrm{g} \cdot \mathrm{L}^{-1}$. For offshore areas, a reduction factor of $60 \%$ (chlorophyll- $a$ threshold 6 and $4 \mu \mathrm{g} . \mathrm{l}^{-1}$ for the offshore areas adjacent to ecotypes NEA $1 / 26 \mathrm{~b}$ and $1 / 26 \mathrm{a}$, respectively) was applied. In WMS, reduction 
factors (and the associated thresholds) were respectively of 30\% $\left(2.0 \mu \mathrm{g} \cdot \mathrm{L}^{-1}\right)$ and $60 \%\left(1.44 \mu \mathrm{g} \cdot \mathrm{L}^{-1}\right)$ for intermediate and offshore areas.

\subsection{Data Integration and Aggregation Scoring System}

As the ultimate goal was to provide a GES or a non-GES status for each reporting marine unit, an aggregation and integration procedure (Figure 2) has been developed through interpretation of guidelines made available by EU working groups [24]. The procedure was also based on the existing methods developed within OSPAR [7]. As a first step, data sets for each criterion were analyzed to establish whether indicators were found at levels exceeding the corresponding assessment threshold, entailing scoring as " + ", or below the threshold as "-" (Table 3). As a second step, integration was conducted at the level of each geographical assessment unit, merging the scores of the different criteria according to a weighting grid (Table 3). When D5C1, D5C2, and D5C5 were above threshold (" + ") a score of 2 was given, since they are causative and direct effects of eutrophication. When D5C4, D5C7 were above threshold (" + ") a score of 1 was given, because they are secondary criteria and not directly specific to eutrophication processes. When a criterion was below the threshold, a score of 0 was given. Once aggregated, the highest the score was, the more likely a non-GES status was expected. For the coastal area, the sum of criteria must not exceed 5, which corresponds to about half of the highest achievable score of 9 for the 6 criteria evaluated, for a geographical assessment unit to be in GES. Note the exception for D5C6, which, if in poor condition, automatically gave a lower grade to the coastal water body (non-GES status). In intermediate and offshore areas, where fewer criteria were assessed, the sum of the criteria for a given GEU were not to exceed 2 to be in GES. If both phosphorus and nitrate were assessed in the same geographical assessment unit, then criterion D5C1 was given a " + " as soon as one of the two elements was above the threshold. If, within a single geographical assessment unit, the assessment was shaped by several criteria (D5C1 and D5C7), the status was determined by the most low grading indicator (Figure 2).

Once the criteria were integrated at the level of the geographical assessment units, aggregation was carried out directly by calculating the percentage of the area for the considered reporting marine unit that have reached or not reached the GES.

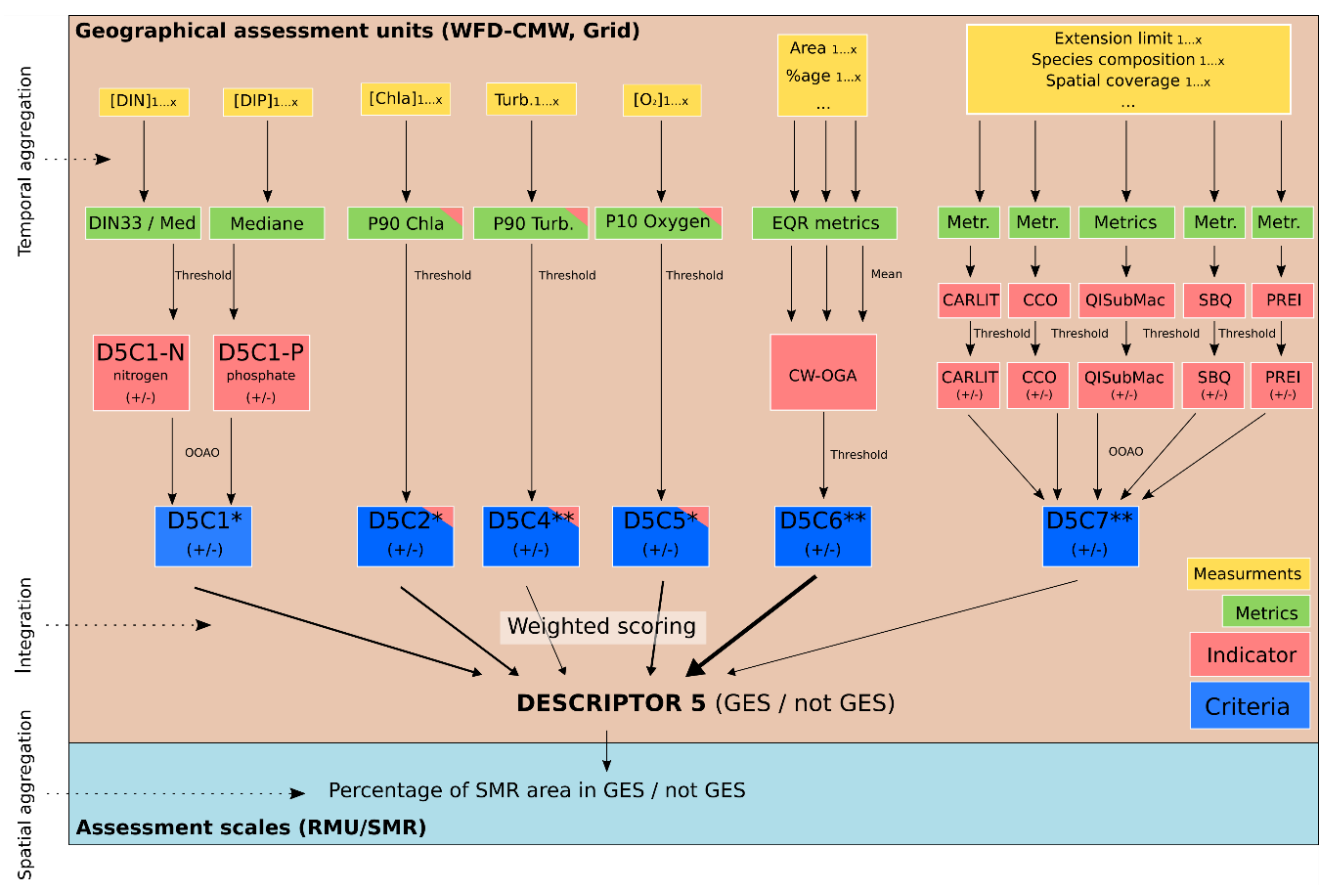

Figure 2. Conceptual model (derived from guidance article 8 [18]) showing how to aggregate and integrate MSFD D5 eutrophication indicators/criteria to assess Good Ecological Status (GES) for French coastal to marine waters. 
Table 3. Scoring system derived from the Oslo and Paris Convention for the Protection of the Northeast Atlantic (OSPAR) eutrophication assessment procedure to define Good Ecological Status (GES) or non-GES status for MSFD D5 eutrophication for French coastal to marine waters at the Geographical Assessment Units scale (nr: Not relevant to use the criterion for the considered area).

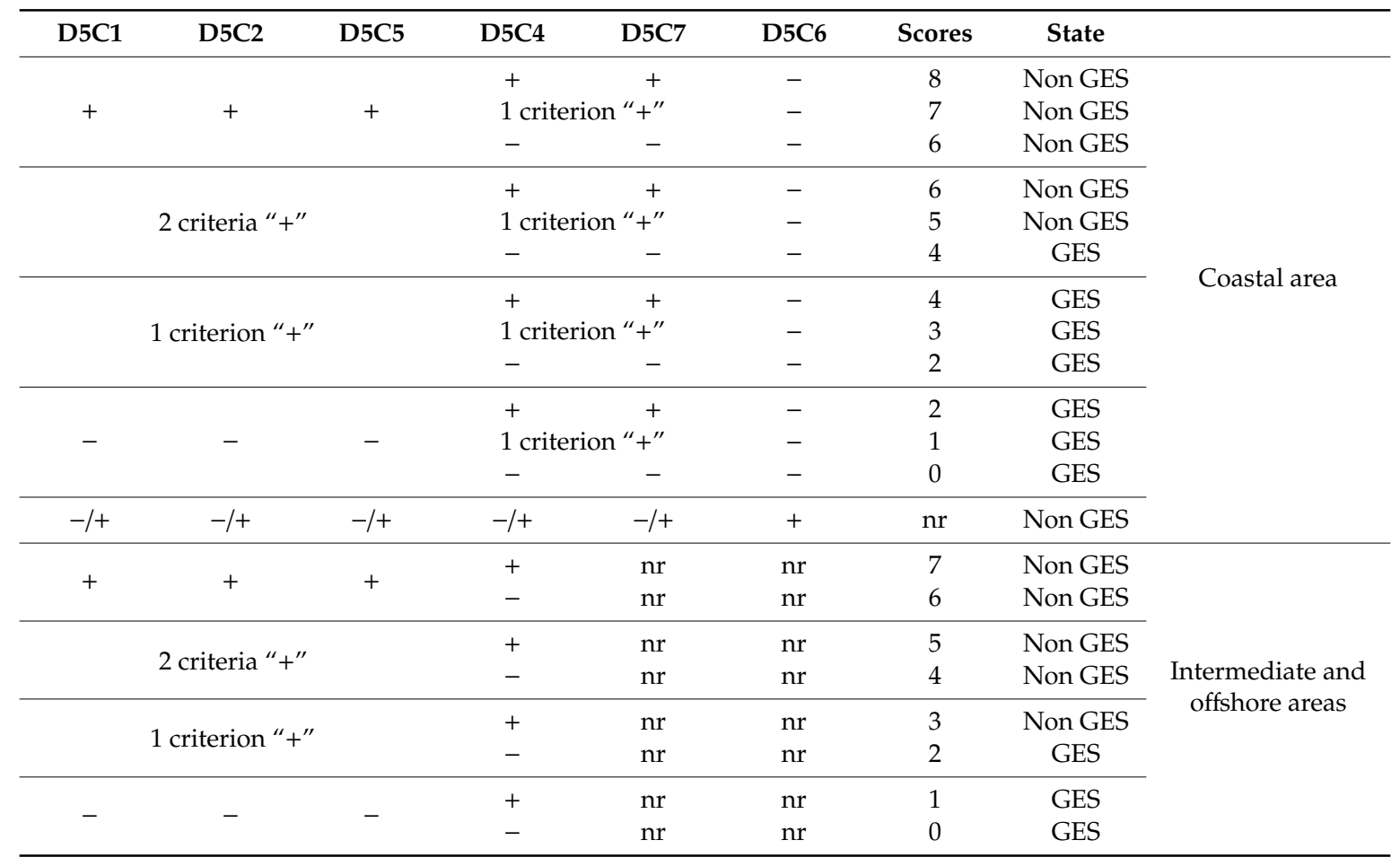

\section{Results}

\subsection{Nutrients (D5C1)}

DIN concentrations resulted in a low grading of GES in the region of fresh water influence from the bay of Seine to the northern part of the Eastern English Channel (Dover Strait) (1076 km², i.e., $45 \%$ of ECNS coastal zone in non-GES status), and within the intermediate area $\left(3308 \mathrm{~km}^{2}\right.$, i.e., $28 \%$ of the surface area in non-GES status) (Table A1 in Appendix A). They were below the threshold for all ECSN offshore waters (100\% GES). DIP (D5C1) concentrations were not assessed in coastal waters (no available threshold) (Table A2 in Appendix A). At the whole ECNS level, $4384 \mathrm{~km}^{2}(16 \%)$ and $2085 \mathrm{~km}^{2}$ (7\%) were in non-GES status, respectively, for DIN and PID.

In CS, all offshore and intermediate waters were in GES status for DIN and DIP (Tables A1 and A2). Four WFD coastal waters $\left(812 \mathrm{~km}^{2}\right.$, i.e., $17 \%$ ) were in non-GES status for DIN.

In BB, all offshore waters were in GES status for DIN and DIP. For DIN, $325 \mathrm{~km}^{2}(4 \%$ of the coastal zone) and $955 \mathrm{~km}^{2}$ (7\% of the intermediate area near the Gironde, the Loire, and the Sèvre Niortaise river plumes) were in non-GES status (Table A1). For DIP, $2367 \mathrm{~km}^{2}(17 \%)$ of the intermediate area were in non-GES status (Table A2).

In WMS, coastal waters were not assessed for DIN and DIP. Only one intermediate area $\left(36 \mathrm{~km}^{2}\right)$ offshore the Rhone river plume was not in GES for DIN. All intermediate and offshore WMS waters were in GES for DIN and DIP (Tables A1 and A2).

\subsection{Chlorophyll-a Concentration (D5C2)}

Chlorophyll- $a$ concentration exceeded the threshold in the ECNS ( 2 coastal waters, $267 \mathrm{~km}^{2}$ ) and the BB (1 coastal water, $152 \mathrm{~km}^{2}$ ). Intermediate waters within the ECNS region of fresh water influence $\left(1700 \mathrm{~km}^{2}\right)$ and in the bay of Seine $\left(902 \mathrm{~km}^{2}\right)$ were in non-GES status (Table A3 in Appendix A). All waters masses were in GES in the CS. Only $32 \mathrm{~km}^{2}$ were in non-GES status in the intermediate area 
of the WMS. In BB, non-GES status was assessed north of the Gironde estuary and in front of the Loire river $\left(168 \mathrm{~km}^{2}\right)$.

\subsection{Turbidity (D5C4)}

Non-GES status for turbidity was of concern in the intermediate areas in ECNS (bay of Seine, $50 \mathrm{~km}^{2}$, i.e., $<1 \%$ ), in BB (in front of the Gironde river, $251 \mathrm{~km}^{2}$, i.e., $<2 \%$ ), and in WMS (in front of the Rhone river, $58 \mathrm{~km}^{2}$, i.e., $<1 \%$ ) (Table A4 in Appendix A).

\subsection{Oxygen Concentration (D5C5)}

All waters masses in ECNS, CS, and WMS sub-marine regions were in GES when considering the oxygen criteria. Results highlighted $912 \mathrm{~km}^{2}$ (i.e., $6 \%$ of the intermediate surface area) of non-GES waters offshore the Arcachon basin in BB SMR (Table A5 in Appendix A). Results for oxygen concentration have to be considered with extreme caution, as the model is not highly reliable for this parameter in the BB area.

\subsection{Abundance of Opportunistic Macroalgae (D5C6)}

This criterion was only assessed in coastal waters. It was not relevant for WMS SMR. The main non-GES status areas were localized in three WFD coastal waters in the bay of Seine $\left(117 \mathrm{~km}^{2}\right.$, i.e., $5 \%$ of the coastal area in ECNS SMR), in four WFD coastal waters in CS $\left(982 \mathrm{~km}^{2}\right.$, i.e., $20 \%$ of the coastal area of this SMR), and in three WFD coastal waters in BB $\left(260 \mathrm{~km}^{2}\right.$, i.e., $3 \%$ of the coastal area).

\subsection{Abundance of Perennial Seaweeds and Seagrasses (D5C7)}

This criterion was also only assessed in coastal waters. It was not relevant for the southern part of the Gironde area in BB. The non-GES status WFD coastal waters were: Seven in ECNS $\left(871 \mathrm{~km}^{2}\right.$, i.e., $36 \%$ of the coastal area), one in CS (Lannion bay, $38 \mathrm{~km}^{2}$, i.e., $<1 \%$ of the coastal area), five in BB $\left(1490 \mathrm{~km}^{2}\right.$, i.e., $18 \%$ of the coastal area), and thirteen in WMS $\left(694 \mathrm{~km}^{2}\right.$, i.e., $15 \%$ of the coastal area).

\subsection{Overall Eutrophication Assessment}

The eutrophication assessment procedure, largely inspired by MSFD, OSPAR, and WFD guidelines and combining in situ, satellite, and modeling products, allowed for an assessment covering $99 \%$ of the French coastal to marine waters surface area.

In the offshore marine area $(>12 \mathrm{~nm})$, all criteria reached GES, and so no eutrophication problems have been identified (Table 4$)$. This was no longer the case in the coastal $(<1 \mathrm{~nm})$ and intermediate $(>1$ and $<12 \mathrm{~nm})$ areas.

Table 4. Absolute $\left(\mathrm{km}^{2}\right)$ and relative (\%) surface area in Good Environmental Status (GES) with regard to eutrophication descriptor D5 for each sub-marine region (SMR) in the English Channel and the southern bight of the North Sea (ECNS), the Celtic Seas (CS), the Bay of Biscay (BB), and the Western Mediterranean Sea (WMS) (NA: Not Assessed).

\begin{tabular}{|c|c|c|c|c|c|c|c|c|c|c|c|c|c|}
\hline \multirow{2}{*}{ SMR } & \multirow{2}{*}{ Surface Area } & \multicolumn{3}{|c|}{ Coastal Area } & \multicolumn{3}{|c|}{ Intermediate Area } & \multicolumn{3}{|c|}{ Offshore Area } & \multicolumn{3}{|c|}{ All SMR } \\
\hline & & GES & No GES & NA & GES & no GES & NA & GES & No GES & NA & GES & no GES & NA \\
\hline SMR ECNS & surface $\left(\mathrm{km}^{2}\right)$ & 2117 & 117 & 183 & 10,703 & 1183 & 0 & 14,045 & 0 & 0 & 26,865 & 1300 & 183 \\
\hline \multirow{2}{*}{ SMR CS } & surface $\left(\mathrm{km}^{2}\right)$ & 3518 & 982 & 373 & 6705 & 0 & 0 & 31,886 & 0 & 0 & 42,109 & 982 & 373 \\
\hline & $\%$ & 72 & 20 & 8 & 100 & 0 & 0 & 100 & 0 & 0 & 97 & 2 & 1 \\
\hline SMR BB & surface $\left(\mathrm{km}^{2}\right)$ & 6078 & 261 & 1793 & 13,866 & 509 & 0 & 165,857 & 0 & 0 & 185,801 & 770 & 1793 \\
\hline SMR WMS & $\%$ & 81 & 0 & 19 & 100 & 0 & 0 & 100 & 0 & 0 & 99 & 0 & 1 \\
\hline \multirow{2}{*}{ All SMR } & surface $\left(\mathrm{km}^{2}\right)$ & 15,479 & 1360 & 3214 & 51,080 & 1705 & 0 & 298,450 & 0 & 0 & 365,009 & 3065 & 3214 \\
\hline & $\%$ & 77 & 7 & 16 & 97 & 3 & 0 & 100 & 0 & 0 & 98 & 1 & 1 \\
\hline
\end{tabular}


In ECNS (Figure 3), it appeared that the eutrophication problem was mostly the result of the combined action of high nutrient (DIN from the D5C1) and high chlorophyll- $a$ (D5C2) concentrations in the bay of Seine and the Eastern English Channel (under the main influence of the Somme, Canche, and Authie rivers). In the bay of Seine, too high opportunistic macroalgae abundance (D5C6) caused a lower grading in three WFD areas.

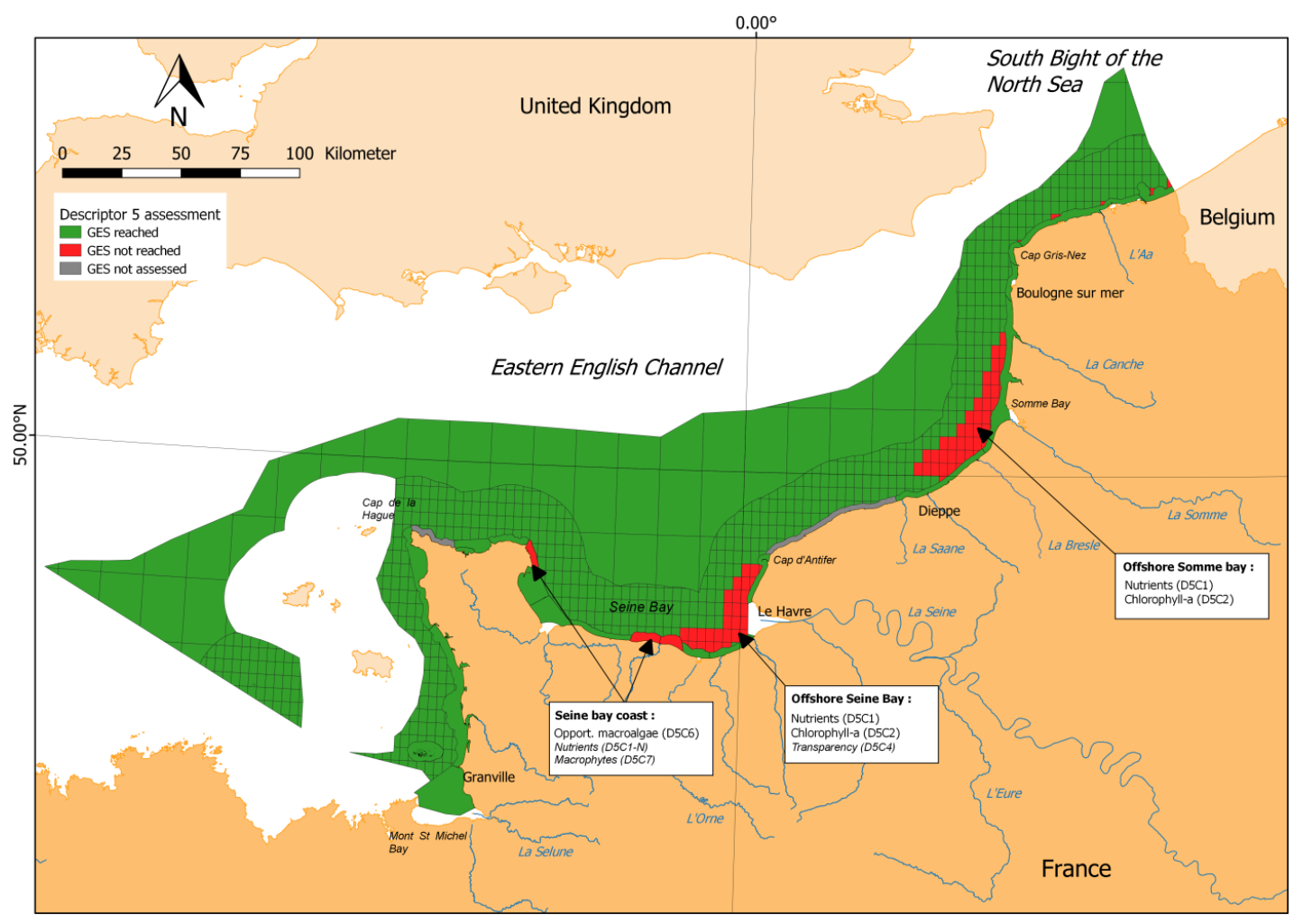

Figure 3. Overall MSFD assessment for descriptor D5 on eutrophication in the English Channel and the southern bight of the North Sea (ECNS) sub-marine region (SMR) (In green: Good Ecological Status (GES); in red: Non-GES status; in gray: Area not assessed). Main criteria which caused a low grading are highlighted for each non-GES area (white box).

In CS (Figure 4), non-GES status was mainly due to high opportunistic macroalgae abundance (D5C6) in four WFD water masses, whereas nutrients (DIN) were not causing a low grading. Only one WFD area exceeded the D5C7 criterion (abundance of perennial seaweeds and seagrasses).

In BB (Figure 5), only three WFD areas were considered not to be able to reach GES, mainly because of green macroalgae blooms. Two intermediate areas of 58 and $230 \mathrm{~km}^{2}$, respectively, under the influence of the Loire and the Gironde rivers, did not reach GES because of nutrients, chlorophyll- $a$ concentrations and/or turbidity (especially for the Gironde river).

In WMS (Figure 6), only a $13 \mathrm{~km}^{2}$ area in front of the Rhone river plume was assessed with a non-GES status because of the combined negative effects of high nutrient and chlorophyll- $a$ concentrations, and high turbidity. 


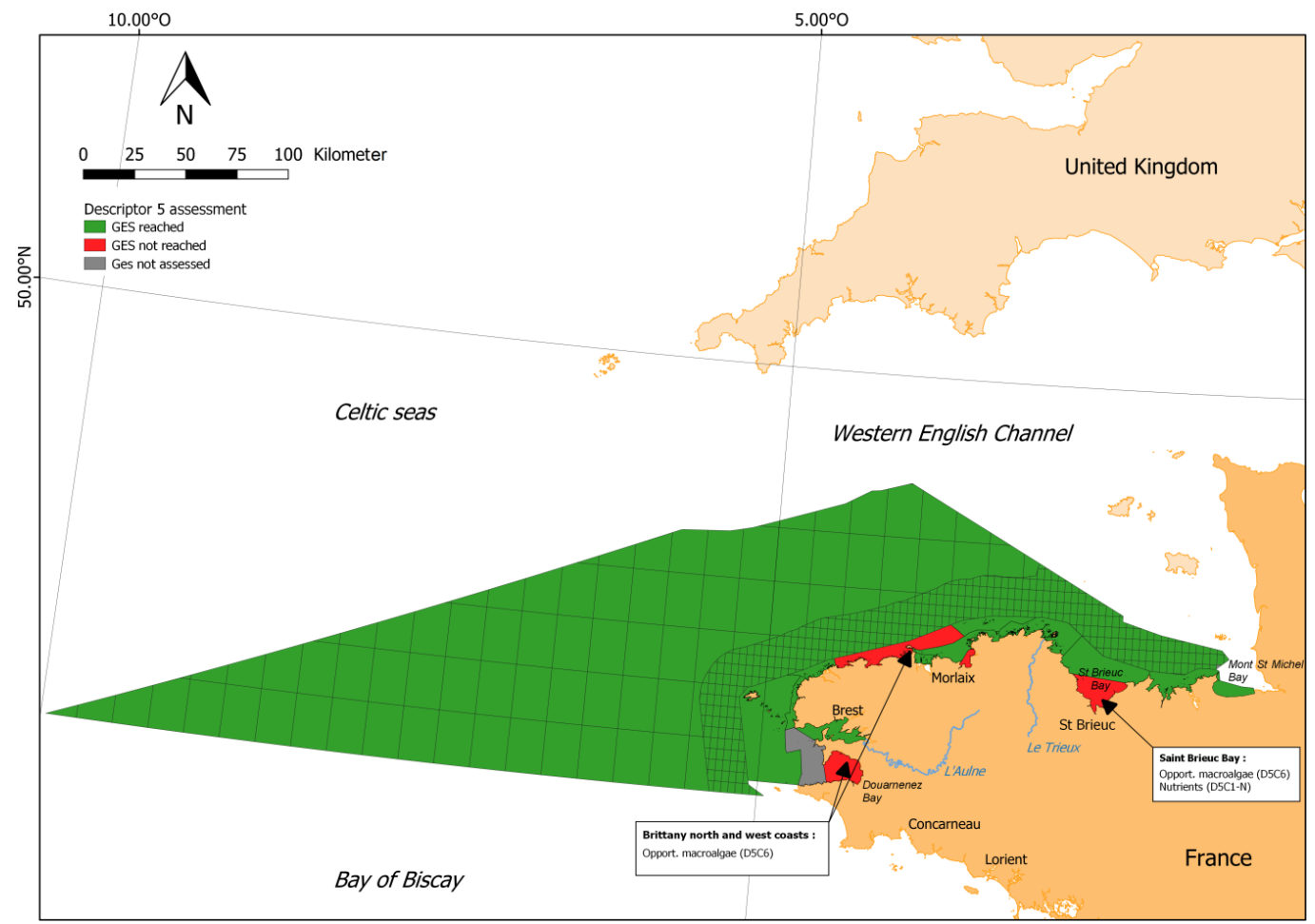

Figure 4. Overall MSFD assessment for descriptor D5 on eutrophication in the Celtic Seas (CS) sub-marine region (SMR) (In green: Good Ecological Status (GES); in red: Non-GES status; in gray: Area not assessed). Main criteria which caused a low grading are highlighted for each non-GES area (white box).

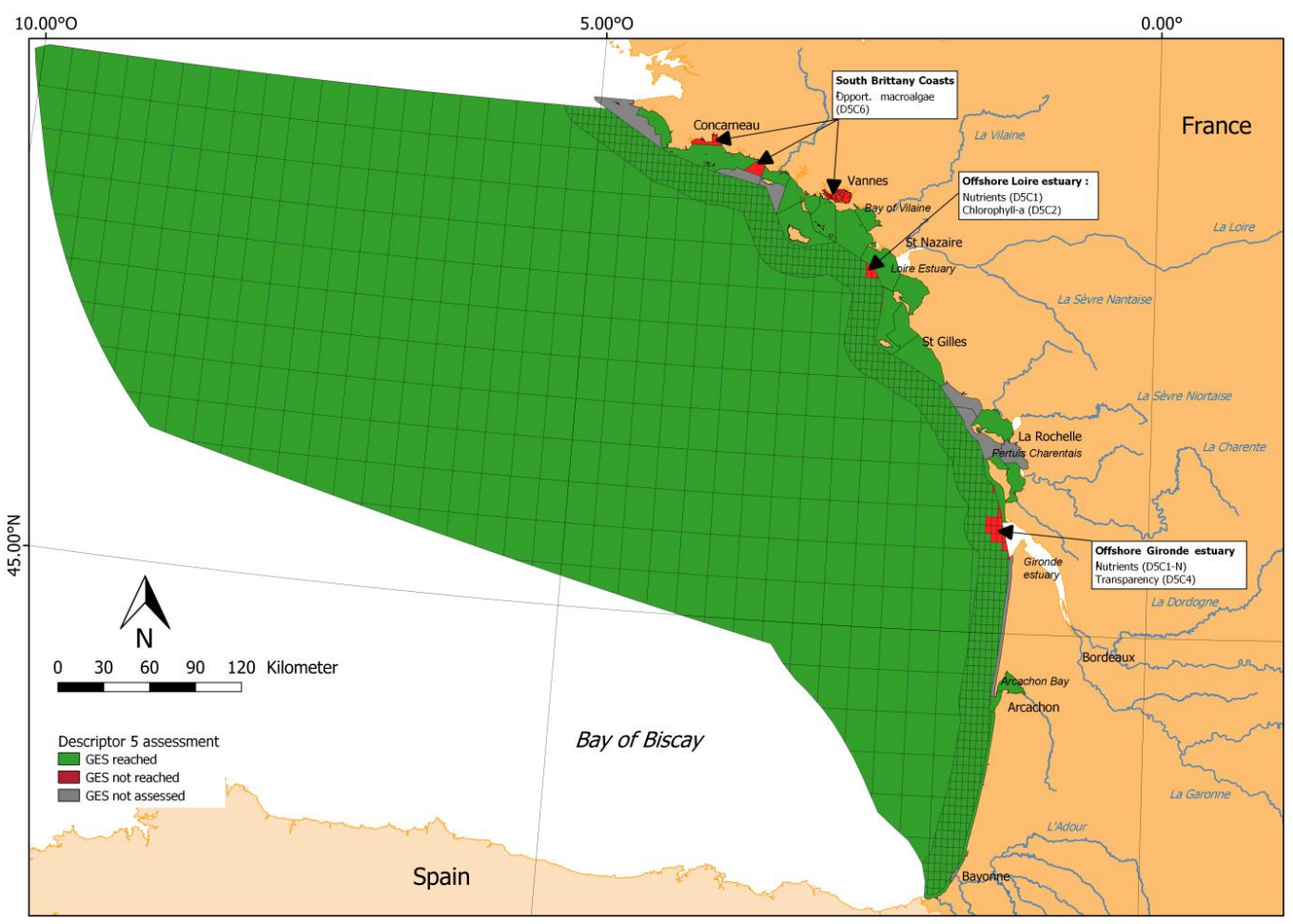

Figure 5. Overall MSFD assessment for descriptor D5 on eutrophication in the Bay of Biscay (BB) sub-marine region (SMR) (In green: Good Ecological Status (GES); in red: Non-GES status; in gray: Area not assessed). Main criteria which caused a low grading are highlighted for each non-GES area (white box). 


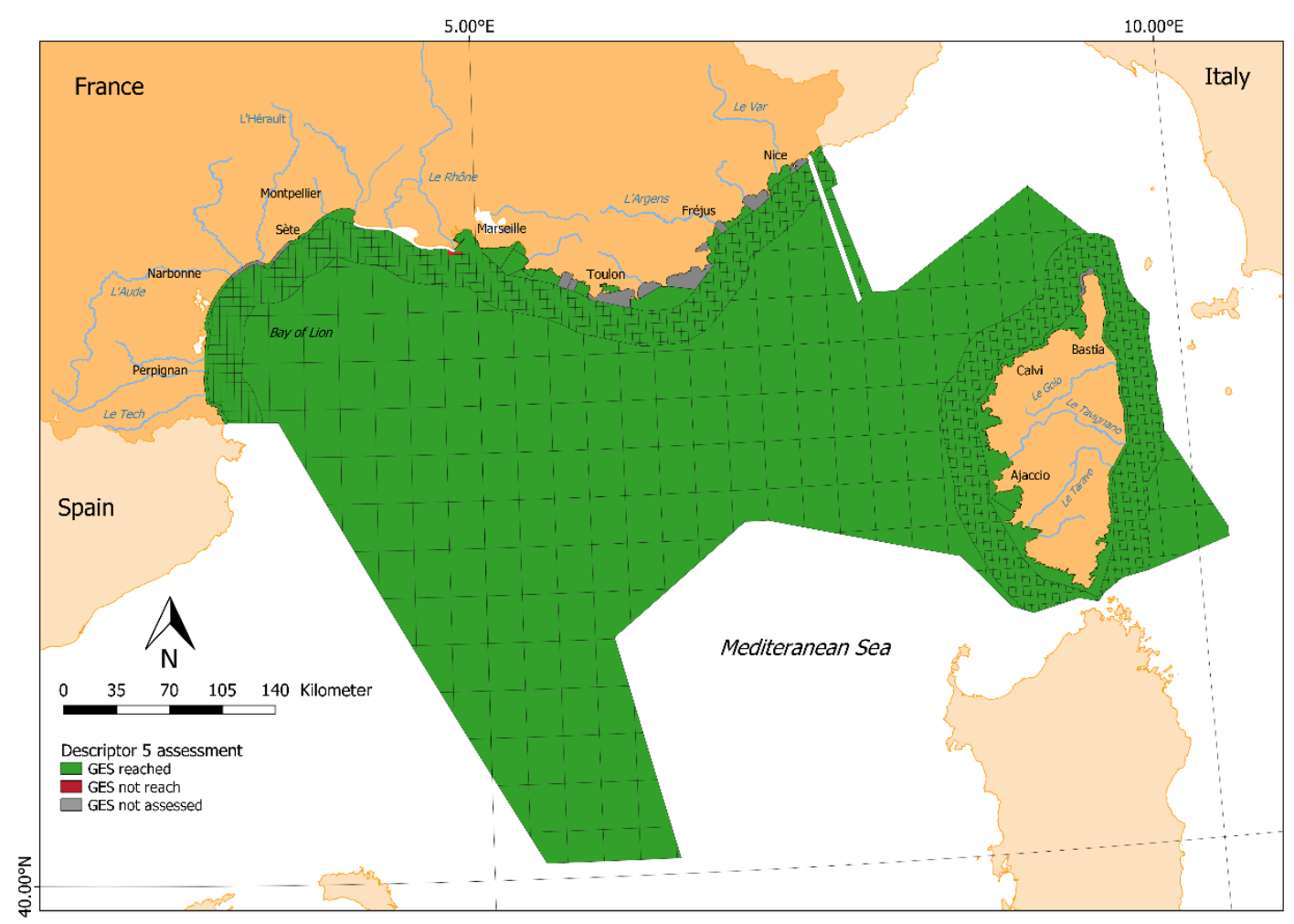

Figure 6. Overall MSFD assessment for descriptor D5 on eutrophication in the Western Mediterranean Sea (WMS) sub-marine region (SMR) (In green: Good Ecological Status (GES); in red: Non-GES status; in gray: Area not assessed).

\subsection{Confidence on Assessment}

While almost all of the sub-marine regions (99\%) were assessed against descriptor 5 (Table 4), not all areas were evaluated with the same confidence level. The mapping of the confidence level, based on the number of criteria used in relation to the number of relevant criteria per GAU (data not shown), shows that this level was particularly high in intermediate and offshore areas (between 0.75 and 1), but was more variable in coastal areas. Indeed, all primary criteria could be assessed in the intermediate and offshore areas for almost all geographical assessment units (due to the high resolution and spatial coverage of the modeling and satellite image products), as well as the relevant secondary criteria (i.e., turbidity). In these areas, only the algal toxicity criterion (D5C3) could not be assessed (no data). Moreover, the criteria D5C6 (opportunistic macroalgae) and D5C7 (macrophytes) were not relevant outside coastal waters. For the coastal area (WFD-like methodology), the number of criteria evaluated for each geographical assessment unit was much more variable, since it only depends on in situ data, so it relies on meteorological conditions to schedule cruises at sea, on human resource availability. DIP was not assessed for any of the water bodies. Moreover, since WFD sampling locations were identified using the WFD ecotype, no data were available for some water masses and we rejected the idea of using data from one ecotype for another.

Whereas the confidence levels for criteria 1 to 5 in the coastal areas were high, some exceptions remained: For D5C2, in ECNS and BB, where the probability was of the order of $75 \%$ or even $55 \%$ for some GAU (near the bay of Seine, the bay of Somme, and the Vilaine and the Loire rivers).

After this initial classification, results were submitted to local experts and stakeholders in order to validate results from this numerical approach, and then to consider possible discrepancies in coastal waters between MSFD and WFD assessment, since integration/aggregation steps were different. Out of twenty-four coastal water bodies in ECNS, seven were reclassified as they needed further investigation to confirm GES status (5 in the Eastern English Channel and 2 near the bay of Seine). They were consequently highlighted as potential problem areas when considering eutrophication. 
This uncertainty about the real GES status in ECNS concerns $25.4 \%$ of the coastal water surface. In the CS area, out of fifteen coastal water bodies, three needed to be considered as potential problem areas (15.7\% of the coastal water surface). In the BB area, among the thirty-four coastal water bodies, three were reclassified as potential problem areas (10.0\% of the coastal water surface). In the WMS area, eleven coastal water bodies out of 46 were mainly reclassified ( $14.7 \%$ of the coastal water surface).

\section{Discussion}

Following the endorsement of the EU Marine Strategy Framework Directive (MSFD) in 2008 and the implementation of the Good Environmental Status (GES) assessment procedure in 2018, discussions are still ongoing to develop guidance for the eleven quality descriptors that form the basis for evaluating ecosystem function, then GES. Existing guidance still proposes general pattern for eutrophication assessment, and since such guidances want to encapsulate the ecosystem variability, they may be interpreted differently, leading to non-harmonized, heterogeneous assessments for a given (sub-) marine region and between EU members. This makes it particularly difficult to integrate with other criteria to move forward a real ecosystem approach. Moreover, uncertainty and inconsistency in results prevent stakeholders and policymakers from endorsing environmental management decisions for maximum effectiveness to reduce non-GES status.

Based on French developments undertaken to prepare the 2018 MSFD D5 (eutrophication descriptor) assessment, the present study proposes the first comprehensive quantitative assessment of the eutrophication status, from coastal to marine French waters in the English Channel, the Celtic Sea, the Bay of Biscay, and the Mediterranean Sea. Our main objective was to propose an overview of the eutrophication status from French coastal $(<1 \mathrm{~nm})$ to offshore waters based on (i) a combination of in situ, remote sensing, and modeling data and (ii) a two-step approach with a numerical assessment leading to an initial classification, then a final classification based on expert judgment.

\subsection{Improvement of Eutrophication Assessment}

Whereas eutrophication status was assessed by OSPAR on a regular basis since 1985, France was not able to provide a full assessment from inshore to offshore waters even during the last exercise for the period 2006-2014. On the basis of a very coastal $(<1 \mathrm{~nm})$ assessment of the ecological status within the EU Water Framework Directive (WFD), the eutrophication monitoring program set up for MSFD second cycle (2012-2018), as well as specific methodological developments, have enabled us to assess the eutrophication status (MSFD descriptor 5) over nearly $99 \%$ of the surface area of French marine waters (371 $288 \mathrm{~km}^{2}$ ). The previous WFD and OSPAR evaluations represented only $5.4 \%$ of MSFD marine regions surface. The combination of in situ data, satellite, and modeling products from a variety of sources has made this possible by bridging the information gap in offshore waters ( $>1 \mathrm{~nm}$, up to the Exclusive Economic Zone). The eutrophication assessment was planned to be carried out in two stages: A pure numerical assessment at the French national scale, leading to an initial classification, then a revision of the assessment by local experts (at the watershed and coastal water scales) leading to a final classification. Differences between initial and final classification were of concern only for 24 coastal water bodies for a total of 119 reporting marine units. The eutrophication assessment, as proposed in this manuscript, is the first quantitative one from coastal to offshore French marine waters. This eutrophication assessment is only part of the ecosystem approach as defined by Borja et al. [25], but a good evaluation for each MSFD descriptor is a first step towards a good overall ecosystem assessment.

Whereas guidelines were available to theoretically help member states to implement MSFD [26-28], they remained too conceptual, and did not provide an operational approach when the experts in charge of the assessment needed to import data, to compute metrics, and to integrate or to aggregate data/assessment results in order to provide the final outcome: GES or not? The choice of criteria and aggregation rules were the responsibility of member states. The "only" constraint was to ensure coherence of frameworks within the different marine regions or sub-regions and across the community. 
Given the short time allowed to experts to make this assessment, it comes as no surprise that the level of harmonization of methodologies used by the different member states is not enough to match MSFD needs.

Despite variety of existing methods for assigning relevant assessment areas (based on salinity gradient, eco-hydrodynamic characteristics), our approach was rather simple, dividing each reporting marine unit in grids of different sizes, from the coastal to the offshore areas. This approach made it possible to clearly visualize the pressure gradients from land to sea. Moreover, such a division also made it possible to better position the sampling points for the monitoring program, and seems well adapted to apply existing methodologies dealing with confidence rating [29]. Such grids are also useful for stakeholders to direct back to programs of measures and river basin management plans. Indeed, such a fine spatial scale in coastal areas is essential to link local pressures from the watershed to marine downstream state and impacts. Intermediate and offshore bigger grids made it possible to assess the extent of the eutrophication problem, and thus to put in place better-dimensioned remediation actions. All MSFD regions were first split into more manageable areas. The choice has been made to propose three reporting marine units (coastal, intermediate, and offshore). Each reporting marine unit was then divided into geographical assessment units; these are the smallest geographical units in which the indicators were calculated. In the intermediate water masses, geographical assessment units were $1 / 20^{\circ}$ width cell size, whereas offshore waters were divided into $1 / 4^{\circ}$ width cell size. Of course, this breakdown implies the proposition of an evaluation for each cell, or the experts have to define criteria to use the same data for neighboring grids having the same environmental characteristics. Moreover, this approach arbitrarily separate waters at the boundary between member states, despite water masses continuities and exchanges. This is the reason why MSFD work for descriptor 7 (Hydrological Conditions) were based on marine landscape characterized by their hydrodynamic characteristics [30]. Meanwhile, the EU project Joint Monitoring Programme of the Eutrophication of the North Sea with Satellite Data (JMP EUNOSAT) [31,32] aims at providing coherent reference conditions and thresholds of chlorophyll- $a$ and primary production against nutrient concentrations that trigger eutrophication in the North Sea. With this project, satellite data made it possible to define assessment areas (i.e., geographical assessment units-like areas). The environmental conditions used in shaping assessment areas were physical, chemical, and biological factors. Combined with French MSFD D7 products, these marine landscapes should be the new OSPAR assessment areas (OSPAR Task Group COMP ongoing works). It is likely that these new assessment areas will be used in the next MSFD D5 assessment. Nevertheless, we should also use our 2018 grid in parallel to take advantage of the added value of such a gridded approach for local environmental managers, and also to compare assessment results.

The indicators used to carry out the present assessment for coastal waters are the ones developed and implemented by France within the framework of WFD. They, nevertheless, required some adaptations to best meet the needs of MSFD for coastal, and mainly for offshore waters. Most of the development concerned D5C1 (Nutrients), D5C2 (Chlorophyll-a), and D5C4 (Water Transparency) criteria, because they are of concern for coastal to offshore areas. For D5C5 (Oxygen), D5C6 (Opportunistic Macroalgae) and D5C7 (Macrophytes Communities), WFD metrics were used, as these criteria were mainly relevant in coastal waters. The only differences were aggregation and integration steps in order to provide an overall coastal-to-offshore assessment without discontinuity at the $1 \mathrm{~nm}$ edge because of methodological differences. Assessment with D5C4 (Harmful Algal Bloom) was not provided as the relationship between eutrophication and harmful algal bloom needs to be confirmed. Moreover, the available threshold was related to a public health issue (accumulation of phycotoxins in shellfish) rather than ecological status. D5C8 (Macrofaunal Community) was not implemented, as D5C5 was used preferentially.

For nutrients, there is an urgent need for convergence of the different approaches proposed by the EU Directives (WFD, MSFD, Nitrates Directive, Urban Wastewater Treatment directive) and Regional Sea Convention (OSPAR). There is a need to harmonize the use of DIN, DIP, total nitrogen (TN), and total 
phosphorus (TP) within monitoring programs and associated assessment tools. For some areas where secondary blooms are expected, TN and TP measurements are relevant since they are less affected by seasonal nutrient conversion process, whereas the inorganic nutrients are seasonally replaced by organic compounds. Since there exists more evidence that there is not only P or N limitation for a given ecosystem [33,34] because limitation can vary both in space and time leading to colimitation, it is recommended not to use a single limiting nutrient to achieve GES. There is a need to consider, at least, a dual approach based on the N:P ratio. Dissolved silica concentration (DSi) has to be considered too within monitoring programs, as background information for the possible shift in phytoplankton groups, from non-silicified to silicified taxa. Recent modification of the upstream eutrophication status could also lead to increasing inputs of DSi to marine coastal waters, enhancing marine phytoplankton growth [35]. The acquisition of Fundable, Available, Interoperable, and Reusable (FAIR) data about nutrient concentrations, river flows (to calculate nutrient fluxes) is a prerequisite to await an acceptable level of knowledge and harmonization for decision-making in the river basin management plan. Modeling is also an essential tool for addressing the land-sea continuum. The results of modeling activities dealing with biogeochemical, hydrodynamical, and biological processes are of primary importance to better understand relationships between pressures, states, and impacts, and they could be used to define nutrient removal scenarios in order to move towards GES $[36,37]$.

The chlorophyll- $a$ concentration indicator is inter-calibrated at the EU level within WFD and is also widely used as a primary criterion for eutrophication assessment. Nevertheless, the improved knowledge on phytoplankton dynamics and the complexity of the involved processes means that assessment of this biological compartment can no longer be limited to its biomass only [38]. There is a clear need for further consideration of phytoplankton biodiversity, functional groups, trait-based approaches to identify community structure changes $[39,40]$ following mainly modifications of nutrient pressures, but also to consider possible effects or other relevant parameters, such as light regime, residence time, etc.

The degree of oxygen deficiency is widely used as an indirect assessment parameter for nutrient enrichment. There appears to be a consensus on assessment levels of the various degrees of oxygen deficiency. The value of $3 \mathrm{mg} \cdot \mathrm{L}^{-1}$ seems to be acceptable to differentiate good from poor status. No more development seems to be necessary for this indicator. Nevertheless, it is more the metric based on a low resolution sampling strategy that has to be revised. Extreme events, leading to hypoxia or anoxia, have to be monitored using high frequency systems such as instrumented buoys.

The link between nutrient enrichment and the incidence of Harmful Algal Blooms (HAB, toxic, or high biomass) is still under investigation. Indeed, depending on the location and environmental conditions, some studies indicate that occurrence of HAB is linked to light, temperature, salinity, or climate and weather processes, rather than nutrient flux [41], whereas others allow us to consider with more confidence that the abundance of some HAB, like Phaeocystis globosa, is related to the concentration of DIN [42]. As a consequence, D5C3 criterion was not used in the French eutrophication assessment.

Turbidity is clearly of importance when considering phytoplankton growth. Actually, even if the nutrient concentration is optimal, then high turbidity can inhibit a phytoplankton outburst. The methodology to be applied for this parameter remains to be confirmed. Indeed, according to member states, water transparency was assessed using turbidity expressed in NTU, NFU units, or in meter (when using the Secchi Depth). Although conversion possibilities exist, the factors used may differ from one region to another, from one season to another, and so on. When dealing with turbidity, the expert must be vigilant with regard to meteorological and hydrodynamic conditions during sampling. The analysis of these conditions can help put a bad result into perspective or confirm a good one. Moreover, a high-resolution sampling strategy (using a buoy, for example) should be of interest to identify extreme events such as storms and floods.

Most of the developments for the benthic compartment are undertaken within the framework of MSFD descriptor 1 (Benthic Habitats) or WFD working groups or specific research studies [43]. For example, thanks to the DEVOTES project, Teixeira et al. [44] proposed a catalogue of marine 
biodiversity indicators. More recently, the BenthoVal project [45] "aims at giving better tools to evaluate the ecological status of habitats and to better understand the spatial and temporal dynamic of benthic diversity (alpha, beta, and gamma). This project will evaluate the Ecological Quality (EcoQ) of coastal benthic habitats of Metropolitan France. It asks fundamental scientific questions, but will provide guidelines that will help implement public policy in the short, mid, and long term. Specific objectives include the development, validation, and application of methods to better evaluate EcoQ of benthic marine habitats". Works are still ongoing on national or EU levels to define what will be the best benthic assessment methodology in the future. MSFD D5 assessment is very dependent on these works.

MSFD assessment requires aggregation and integration of many data sources. It is well known that the choice of the method can considerably affect the assessment outcome [46,47]. The MSFD methodological recommendations were such that WFD approach should be considered for coastal waters and draw on the work of the Regional Seas Conventions (OSPAR) for offshore waters. Unfortunately, WFD and OSPAR approaches were not harmonized (One Out All Out vs. the scoring method, respectively) which made it difficult to propose a method that would not cause a break in assessment between coastal $(<1 \mathrm{~nm})$ and offshore waters. The One Out All Out principle, the "worst status element" approach, often leads to false positive error (i.e., leading a waterbody to reach a worse class status), and so it is regarded as a precautionary approach. According to Borja and Rodriguez [48], it is just a starting point when dealing with aggregation/integration rules, and it should be avoided. Consequently, the French eutrophication assessment approach was based on a less penalizing method derived from OSPAR. Results were considered satisfactory during the 2006-2014 assessment. After a spatial aggregation of data available for a given criterion and for each GAU on the assessment period, a scoring method has been implemented to set if the considered criterion was above threshold (score + ) or not (score -). So, scores for each criterion have been integrated, considering a weighting grid to classify each geographical assessment unit with a GES or a non-GES status. The OOAO approach was only used to directly give a non-GES status when D5C6 (opportunistic macroalgae) criterion was above threshold, as there is a consensus on the positive relationship between excessive nutrient inputs and macrophytes abundances $[49,50]$.

\subsection{Identification of the Main Pressures}

The use of an adaptive grid from the coastal to the offshore area as a geographical assessment unit enabled us to identify precisely the areas impacted by eutrophication problems (the area from the bay of Seine to the Picard estuaries, part of the Brittany coast, off the Loire and the Gironde river plumes), but also to assess with some precision the surface area concerned (Table 3). For each grid at sea, the objective was then to identify the main pressures on the catchment area, leading to a lower status (non-GES status). Based on this pressure/state/impact census, it should be possible to propose Environmental Objectives within the Programme of Measure pursuant to Article 13 of MSFD (program of cost-effective measures to attain Good Environmental Status).

Based on OSPAR Riverine Input Data (1989-2015) and reports [51], it may be concluded that there has been a general reduction in nitrogen inputs since 1990, but trends were weak or absent for most of the rivers discharging in ECNS, CS, BB, and WMS. Conversely, phosphorus inputs have significantly decreased since 1990, and a monotonous linear decreasing trend was observed. Beyond these general trends, it was noteworthy that nitrogen inputs (total $\mathrm{N}$ or nitrate) increased in the eastern English Channel (from the bay of Somme to the Belgian border) and for some tributaries and minor rivers in BB (La Boutonne and La Livenne tributaries of the Adour-Garonne river) and in WMS (La Siagne, La Gravonne, Le Tavaro). More generally, pressures on EU rivers remained relatively high despite considerable effort to banish excessive nutrient uses [52].

Atmospheric inputs also need to be carefully considered, as they should account for a significant portion of nutrient inputs (10 to 30\%) [53]. The Comprehensive Atmospheric Monitoring Programme (CAMP) aims at assessing the input of selected contaminants to OSPAR maritime area and its regions via atmospheric deposition [54]. OSPAR used EMEP's (European Monitoring and Evaluation 
Programme) modeled products for atmospheric deposition of selected contaminants. Assessment of nutrient emission and deposition were only available at the OSPAR region scale. Consequently, it was difficult to propose a quantification of nutrient emission and deposition for each sub-marine region. Nevertheless, based on the assessment period 1980-2014, N deposition and emission showed a clear decreasing trend for OSPAR Regions II and III (related to ECNS and CS), and Region IV (related to BB). Emissions of oxidized nitrogen came mainly from agriculture, while emissions of reduced nitrogen came from industrial combustion and maritime transport.

\subsection{Recommendations for Future Assessments}

Considering our specific eutrophication assessment experience, and as already mentioned by Claussen et al. [2] in line with OSPAR science agenda [55], the main subjects to focus on for better future quantitative ecological status assessments should be: Area specification and typing, pressures/status/impact relationships (including climatic change cumulative and synergetic effects), harmonized references and thresholds, relevant temporal and spatial resolutions, integration of confidence rating, and modeling of nutrient fluxes along the land-sea continuum (including nutrient reduction scenarios). Work on these subjects must be based on a good knowledge of eutrophication processes, their dynamics, and on a high-level quality research, the themes of which have been proposed by Ferreira et al. [28].

It seems appropriate to maintain a two-phase evaluation. The first step is to apply the recommended metrics to the available data sets. An initial, purely numerical evaluation is thus obtained. It can be automated using a dedicated calculation tool (e.g., HELCOM HEAT [56]) created by the experts in charge of the evaluation at a national level or even on a larger scale in order to facilitate the inter-comparability of the results obtained. The second step is to propose this assessment to local scientific experts, water agencies, and stakeholders so that they can take into account studies and research specific to their areas. Thus, the initial assessment can be modified to arrive at the final classification, being then the reference. This stage of local expertise must be framed and the proposed modifications must be argued and officially referenced. These modifications must be traceable.

As innovative technologies and associated numerical methodologies have been considerably improved over recent years (see, for example, deliverables from the JERICO-NEXT project: http: //www.jerico-ri.eu/), it seems feasible to consider new data sources, such as those from buoys, ferry boxes (i) for the assessment status purposes but with consideration on consequences on metrics which development was based on low resolution data sources) or (ii) as supplementary information to enhance the overall final classification. The complementarity of low- and high-resolution approaches should make it possible to take into account all the processes that explain the functioning of marine ecosystems, from cells, from the population to community scale, from the local to the regional spatial scale (as exemplified for phytoplankton bloom in [57]).

This integration of data from diverse and complementary sources implies the implementation of an optimized data flow from the local to the national or even European level. Numerous EU initiatives exist to propose databases and data portals for access to environmental data (ICES DOME, Emodnet, Copernicus). More generally, as highlighted by the worldwide platform for global coastal and ocean observation, ILTER, "understanding the threats to global biodiversity and ecosystem services posed by human impacts on coastal and marine environments requires the establishment and maintenance of ecological observatories that integrate the biological, physical, geological, and biogeochemical aspects of ecosystems" [58]. These developments are to be pursued in a harmonized, optimized manner to enable users of these data to easily find what they are looking for, without having to multiply the channels of access to these data.

Author Contributions: A.L. was particularly involved in data curation, formal analysis, funding acquisition, investigation, methodology, project administration, resources, supervision, validation, and writing. D.D. mainly contributed to data curation, formal analysis, investigation, methodology, software, and writing. Both authors have read and agreed to the publication of the manuscript. 
Funding: This work was funded by the French Ministry in charge of the Environment (MTES/DEB) through an agreement with Ifremer.

Acknowledgments: The authors are very grateful to colleagues from French Water Agencies, from Regional Directorate for the Environment and Coastal Development (DREAL), and from several WFD/MSFD/OSPAR Working Groups for fruitful discussions about the MSFD assessment. The authors would particularly like to acknowledge A. Ménesguen, F. Gohin, D. Soudant, and M. Brun (Ifremer) for data extraction and processing related to the WFD water masses, satellite, and modeling data products. S. Derien (MNHN) and A. Foveau (Ifremer) are also acknowledged for their contribution to the benthic compartment status assessment.

Conflicts of Interest: The authors declare no conflict of interest. The funder had no role in the design of the study; in the collection, analyses, or interpretation of data; in the writing of the manuscript; or in the decision to publish the results.

\section{Appendix A}

Table A1. Absolute $\left(\mathrm{km}^{2}\right)$ and relative (\%) surface area in Good Environmental Status (GES) with regard to DIN (D5C1) for each sub-marine region (SMR) in the English Channel and the southern bight of the North Sea (ECNS), the Celtic Seas (CS), the Bay of Biscay (BB), and the Western Mediterranean Sea (WMS) (NA: Not Assessed).

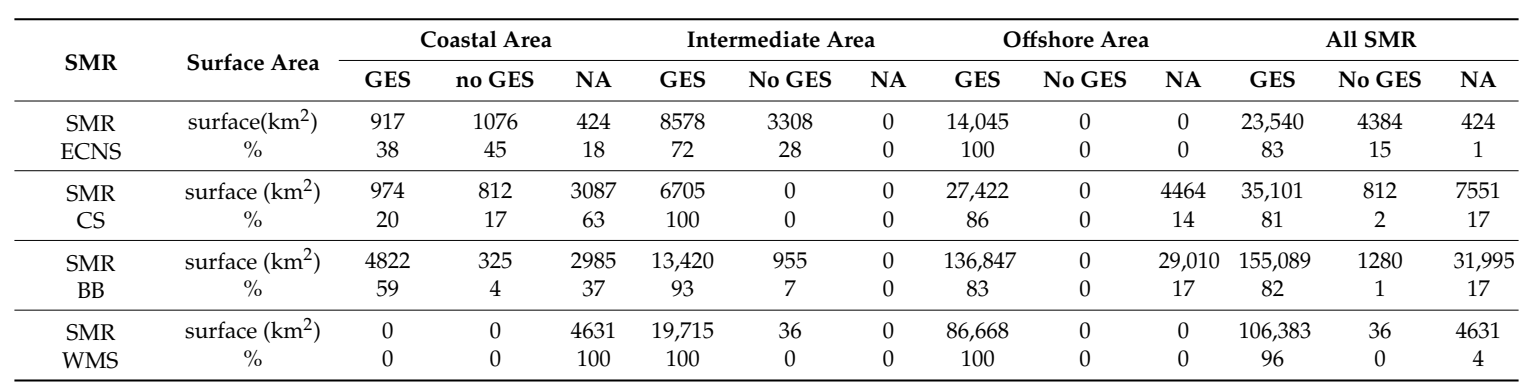

Table A2. Absolute $\left(\mathrm{km}^{2}\right)$ and relative (\%) surface area in Good Environmental Status (GES) with regard to DIP (D5C1) for each sub-marine region (SMR) in the English Channel and the southern bight of the North Sea (ECNS), the Celtic Seas (CS), the Bay of Biscay (BB), and the Western Mediterranean Sea (WMS) (NA: Not Assessed).

\begin{tabular}{|c|c|c|c|c|c|c|c|c|c|c|c|c|c|}
\hline \multirow{2}{*}{ SMR } & \multirow{2}{*}{ Surface Area } & \multicolumn{3}{|c|}{ Coastal Area } & \multicolumn{3}{|c|}{ Intermediate Area } & \multicolumn{3}{|c|}{ Offshore Area } & \multicolumn{3}{|c|}{ All SMR } \\
\hline & & GES & No GES & NA & GES & No GES & NA & GES & No GES & NA & GES & No GES & NA \\
\hline SMR ECNS & surface $\left(\mathrm{km}^{2}\right)$ & 0 & 0 & 2417 & 9801 & 2085 & 0 & 14,045 & 0 & 0 & 23,846 & 2085 & 2417 \\
\hline \multirow{2}{*}{ SMR CS } & surface $\left(\mathrm{km}^{2}\right)$ & 0 & 0 & 4873 & 6705 & 0 & 0 & 27,422 & 0 & 4464 & 34,127 & 0 & 9337 \\
\hline & $\%$ & 0 & 0 & 100 & 100 & 0 & 0 & 86 & 0 & 14 & 79 & 0 & 21 \\
\hline SMR BB & surface $\left(\mathrm{km}^{2}\right)$ & 0 & 0 & 8132 & 12,008 & 2367 & 0 & 136,847 & 0 & 29,010 & 148,855 & 2367 & 37,142 \\
\hline SMR WMS & $\%$ & 0 & 0 & 100 & 100 & 0 & 0 & 100 & 0 & 0 & 96 & 0 & 4 \\
\hline
\end{tabular}

Table A3. Absolute $\left(\mathrm{km}^{2}\right)$ and relative (\%) surface area in Good Environmental Status (GES) with regard to Chlorophyll- $a$ concentration (D5C2) for each sub-marine region (SMR) in the English Channel and the southern bight of the North Sea (ECNS), the Celtic Seas (CS), the Bay of Biscay (BB), and the Western Mediterranean Sea (WMS) (NA: Not Assessed).

\begin{tabular}{|c|c|c|c|c|c|c|c|c|c|c|c|c|c|}
\hline \multirow{2}{*}{ SMR } & \multirow{2}{*}{ Surface Area } & \multicolumn{3}{|c|}{ Coastal Area } & \multicolumn{3}{|c|}{ Intermediate Area } & \multicolumn{3}{|c|}{ Offshore Area } & \multicolumn{3}{|c|}{ All SMR } \\
\hline & & GES & No GES & NA & GES & No GES & NA & GES & No GES & NA & GES & No GES & NA \\
\hline SMR ECNS & surface $\left(\mathrm{km}^{2}\right)$ & 1886 & 267 & 264 & 9285 & 2601 & 0 & 14,045 & 0 & 0 & 25,216 & 2868 & 264 \\
\hline \multirow{2}{*}{ SMR CS } & surface $\left(\mathrm{km}^{2}\right)$ & 1786 & 0 & 3087 & 6705 & 0 & 0 & 31,886 & 0 & 0 & 40,377 & 0 & 3087 \\
\hline & $\%$ & 37 & 0 & 63 & 100 & 0 & 0 & 100 & 0 & 0 & 93 & 0 & 7 \\
\hline SMR BB & surface $\left(\mathrm{km}^{2}\right)$ & 4994 & 152 & 2985 & 14,207 & 168 & 0 & 165,857 & 0 & 0 & 185,058 & 320 & 2985 \\
\hline SMR WMS & $\%$ & 67 & 0 & 33 & 100 & 0 & 0 & 100 & 0 & 0 & 99 & 0 & 1 \\
\hline
\end{tabular}


Table A4. Absolute $\left(\mathrm{km}^{2}\right)$ and relative (\%) surface area in Good Environmental Status (GES) with regard to water transparency (turbidity) (D5C4) for each sub-marine region (SMR) in the English Channel and the southern bight of the North Sea (ECNS), the Celtic Seas (CS), the Bay of Biscay (BB), and the Western Mediterranean Sea (WMS) (NA: Not Assessed).

\begin{tabular}{|c|c|c|c|c|c|c|c|c|c|c|c|c|c|}
\hline \multirow{2}{*}{ SMR } & \multirow{2}{*}{ Surface Area } & \multicolumn{3}{|c|}{ Coastal Area } & \multicolumn{3}{|c|}{ Intermediate Area } & \multicolumn{3}{|c|}{ Offshore Area } & \multicolumn{3}{|c|}{ All SMR } \\
\hline & & GES & no GES & NA & GES & No GES & NA & GES & No GES & NA & GES & No GES & NA \\
\hline \multirow{2}{*}{ SMR ECNS } & surface $\left(\mathrm{km}^{2}\right)$ & 2137 & 0 & 280 & 11,836 & 50 & 0 & 14,045 & 0 & 0 & 28,018 & 50 & 280 \\
\hline & $\%$ & 88 & 0 & 12 & 100 & 0 & 0 & 100 & 0 & 0 & 99 & 0 & 1 \\
\hline \multirow{2}{*}{ SMR CS } & surface $\left(\mathrm{km}^{2}\right)$ & 3106 & 0 & 1767 & 6705 & 0 & 0 & 31,886 & 0 & 0 & 41,697 & 0 & 1767 \\
\hline & $\%$ & 64 & 0 & 36 & 100 & 0 & 0 & 100 & 0 & 0 & 96 & 0 & 4 \\
\hline SMR BB & surface $\left(\mathrm{km}^{2}\right)$ & 5147 & 0 & 2984 & 13885 & 251 & 0 & 165,857 & 0 & 0 & 184,889 & 251 & 2984 \\
\hline SMR WMS & $\%$ & 49 & 0 & 51 & 100 & 0 & 0 & 100 & 0 & 0 & 98 & 0 & 2 \\
\hline
\end{tabular}

Table A5. Absolute $\left(\mathrm{km}^{2}\right)$ and relative (\%) surface area in Good Environmental Status (GES) with regard to oxygen concentration (D5C5) for each sub-marine region (SMR) in the English Channel and the southern bight of the North Sea (ECNS), the Celtic Seas (CS), the Bay of Biscay (BB), and the Western Mediterranean Sea (WMS) (NA: Not Assessed).

\begin{tabular}{|c|c|c|c|c|c|c|c|c|c|c|c|c|c|}
\hline \multirow{2}{*}{ SMR } & \multirow{2}{*}{ Surface Area } & \multicolumn{3}{|c|}{ Coastal Area } & \multicolumn{3}{|c|}{ Intermediate Area } & \multicolumn{3}{|c|}{ Offshore Area } & \multicolumn{3}{|c|}{ All SMR } \\
\hline & & GES & No GES & NA & GES & No GES & NA & GES & No GES & NA & GES & No GES & NA \\
\hline SMR ECNS & surface $\left(\mathrm{km}^{2}\right)$ & 2137 & 0 & 280 & 11,886 & 0 & 0 & 14,045 & 0 & 0 & 28,068 & 0 & 280 \\
\hline \multirow{2}{*}{ SMR CS } & surface $\left(\mathrm{km}^{2}\right)$ & 1786 & 0 & 3087 & 6705 & 0 & 0 & 27,422 & 0 & 4464 & 35,913 & 0 & 7551 \\
\hline & $\%$ & 37 & 0 & 63 & 100 & 0 & 0 & 86 & 0 & 14 & 83 & 0 & 17 \\
\hline SMR BB & surface $\left(\mathrm{km}^{2}\right)$ & 4619 & 0 & 3512 & 13,218 & 912 & 0 & 136,847 & 0 & 29,010 & 154,684 & 912 & 32,522 \\
\hline \multirow{2}{*}{ SMR WMS } & surface $\left(\mathrm{km}^{2}\right)$ & 152 & 0 & 4479 & 19,757 & 0 & 0 & 86,668 & 0 & 0 & 106,577 & 0 & 4479 \\
\hline & $\%$ & 3 & 0 & 97 & 100 & 0 & 0 & 100 & 0 & 0 & 96 & 0 & 4 \\
\hline
\end{tabular}

\section{References}

1. Le Moal, M.; Gascuel-Odoux, C.; Ménesguen, A.; Souchon, Y.; Étrillard, C.; Levain, A.; Moatar, F.; Pannard, A.; Souchu, P.; Lefebvre, A.; et al. Eutrophication: A new wine in an old bottle? Sci. Total Environ. 2019, 651, 1-11. [CrossRef] [PubMed]

2. Claussen, U.; Zevenboom, W.; Brockmann, U.; Topcu, D.; Bot, P. Assessment of the eutrophication status of transitional, coastal and marine waters within OSPAR. Hydrobiologia 2009, 629, 49-58. [CrossRef]

3. European Commission. Nitrates Directive 91/676/EEC. Off. J. Eur. Commun. 1991. Available online: https:/ec.europa.eu/environment/water/water-nitrates/index_en.html (accessed on 24 July 2020).

4. European Commission. Urban Wastewater Treatment Directive 91/271/EEC. Off. J. Eur. Commun. 1991. Available online: https://ec.europa.eu/environment/water/water-urbanwaste/index_en.html (accessed on 24 July 2020).

5. European Commission. Directive 2000/60/EC of the European parliament and of the Council of 23 October 2000 establishing a framework for Community action in the field of water policy or, in short, the EU Water Framework Directive. Off. J. Eur. Commun. 2000, L 327, 1-72.

6. European Commission. MSFD Directive 2008/56/EC of the European Parliament and of the Council of 17 June 2008 establishing a framework for community action in the field of marine environmental policy (Marine Strategy Framework Directive) (Text with EEA relevance). Off. J. Eur. Commun. 2008. Available online: https://eur-lex.europa.eu/legal-content/EN/TXT/?uri=CELEX\%3A32008L0056 (accessed on 24 July 2020).

7. OSPAR Commission. Common Procedure for the Identification of the Eutrophication Status of the OSPAR Maritime Area. Agreement 2013, 1-66. Available online: https:/www.ospar.org/work-areas/hasec/ eutrophication/common-procedure (accessed on 24 July 2020).

8. Backer, H.; Leppänen, J.-M.; Brusendorff, A.C.; Forsius, K.; Stankiewicz, M.; Mehtonen, J.; Pyhälä, M.; Laamanen, M.; Paulomäki, H.; Vlasov, N.; et al. HELCOM Baltic Sea Action Plan-A regional programme of measures for the marine environment based on the Ecosystem Approach. Mar. Pollut. Bull. 2010, 60, 642-649. [CrossRef] 
9. UNEP-MAP Mediterranean Action Plan. Eutrophication Monitoring Strategy for the MED POL (revision). English 2007, 14. Available online: https://www.unenvironment.org/unepmap/ (accessed on 24 July 2020).

10. Borja, A.; Elliott, M.; Carstensen, J.; Heiskanen, A.-S.; Van De Bund, W.; Elliott, M. Marine management-Towards an integrated implementation of the European Marine Strategy Framework and the Water Framework Directives. Mar. Pollut. Bull. 2010, 60, 2175-2186. [CrossRef]

11. Lewison, R.L.; Rudd, M.A.; Al-Hayek, W.; Baldwin, C.; Beger, M.; Lieske, S.N.; Jones, C.; Satumanatpan, S.; Junchompoo, C.; Hines, E. How the DPSIR framework can be used for structuring problems and facilitating empirical research in coastal systems. Environ. Sci. Policy 2016, 56, 110-119. [CrossRef]

12. REPHY. REPHY dataset-French Observation and Monitoring Program for Phytoplankton and Hydrology in Coastal Waters. 1987-2016. Metropolitan Data. SEANOE 2017. [CrossRef]

13. SRN. SRN dataset-Regional Observation and Monitoring Program for Phytoplankton and Hydrology in the Eastern English Channel. SEANOE 2017. [CrossRef]

14. REBENT. Network Benthic Invertebrates Abundance Data in ODV Format from French REBENT Network. SEANOE 2019. [CrossRef]

15. REBENT. Network Intertidal and Subtidal Macroalgae Taxa Data in ODV Format from French REBENT Network. SEANOE 2019. [CrossRef]

16. Gohin, F.; Druon, J.; Lampert, L. A five channel chlorophyll concentration algorithm applied to SeaWiFS data processed by SeaDAS in coastal waters. Int. J. Remote Sens. 2002, 23, 1639-1661. [CrossRef]

17. Gohin, F.; Van der Zande, D.; Tilstone, G.; Eleveld, M.A.; Lefebvre, A.; Andrieux-Loyer, F.; Blauw, A.N.; Bryère, P.; Devreker, D.; Garnesson, P.; et al. Twenty years of satellite and in situ observations of surface chlorophyll-a from the northern Bay of Biscay to the eastern English Channel. Is the water quality improving? Remote Sens. Environ. 2019, 233, 111343. [CrossRef]

18. O’Reilly, J.E.; Maritorena, S.; Mitchell, B.G.; Siegel, D.A.; Carder, K.L.; Garver, S.A.; Kahru, M.; Mcclain, C. Ocean color chlorophyll algorithms for SeaWiFS encompassing chlorophyll concentrations between. J. Geophys. Res. 1998, 103, 24937-24953. [CrossRef]

19. O'Reilly, J.E.; Werdell, P.J. Chlorophyll algorithms for ocean color sensors-OC4, OC5 \& OC6. Remote Sens. Environ. 2019, 229, 32-47. [CrossRef]

20. Ménesguen, A.; Dussauze, M.; Dumas, F.; Thouvenin, B.; Garnier, V.; Lecornu, F.; Répécaud, M. Ecological model of the Bay of Biscay and English Channel shelf for environmental status assessment part 1: Nutrients, phytoplankton and oxygen. Ocean Model. 2019, 133, 56-78. [CrossRef]

21. Cossarini, G.; Mariotti, L.; Feudale, L.; Mignot, A.; Salon, S.; Taillandier, V.; Teruzzi, A.; D’Ortenzio, F. Towards operational 3D-Var assimilation of chlorophyll Biogeochemical-Argo float data into a biogeochemical model of the Mediterranean Sea. Ocean Model. 2019, 133, 112-128. [CrossRef]

22. Moigne, M.L.; Gauthier, E.; Vigies, D. EMODnet-Chemistry Data Qualification Processes for French Coastal Data in Q2; 2015; Available online: https://archimer.ifremer.fr/doc/00315/42612/ (accessed on 24 July 2020).

23. Kushary, D. Bootstrap Methods and Their Application. Technometrics 2000, 42, 216. [CrossRef]

24. Walmsley, S.F.; Weiss, A.; Claussen, U.; Connor, D. ABPmer Draft guidance for assessments under Article 8 of the MSFD. Integration of assessments results. In Proceedings of the 17th Meeting of the Working Group on Good Environmental Status, Brussels, Belgium, 10 March 2017; DG Environment: Brussels, Belgium, 2017; p. 161.

25. Borja, A.; Elliott, M.; Andersen, J.H.; Berg, T.; Carstensen, J.; Halpern, B.S.; Heiskanen, A.S.; Korpinen, S.; Lowndes, J.S.S.; Martin, G.; et al. Overview of integrative assessment of marine systems: The ecosystem approach in practice. Front. Mar. Sci. 2016, 3, 1-20. [CrossRef]

26. Claussen, U.; Connor, D.; de Vrees, L.; Leppänen, J.; Percelay, J.; Kapari, M.; Mihail, O.; Ejdung, G.; Rendell, J. Common Understanding of (Initial) Assessment, Determination of Good Environmental Status (GES) and Establishment of Environmental Targets (Art. 8, 9 \& 10 MSFD). WG GES EU MSFD WG GES $E U$. Available online: https://www.google.com/url?sa=t\&rct=j\&q=\&esrc=s\&source=web\&cd=\&ved= 2ahUKEwi3io6FgebqAhXEy4UKHZvcCRAQFjAAegQIAxAB\&url=https\%3A\%2F\%2Fcircabc.europa.eu \% 2Fsd\%2Fd\%2Fce7e2776-6ac6-4a41-846f-a04832c32da7\%2F05_Info_Common_understanding_final.pdf\& usg=AOvVaw1AWm3jGWgvvbPmsi2YtlGV (accessed on 20 July 2020).

27. Borja, A.; Elliott, M.; Andersen, J.H.; Cardoso, A.C.; Carstensen, J.; Ferreira, J.G.; Heiskanen, A.-S.; Marques, J.C.; Neto, J.M.; Teixeira, H.; et al. Good Environmental Status of marine ecosystems: What is it and how do we know when we have attained it? Mar. Pollut. Bull. 2013, 76, 16-27. [CrossRef] [PubMed] 
28. Ferreira, J.G.; Andersen, J.H.; Borja, A.; Bricker, S.B.; Camp, J.; da Silva, M.C.; Garcés, E.; Heiskanen, A.-S.; Humborg, C.; Ignatiades, L.; et al. Overview of eutrophication indicators to assess environmental status within the European Marine Strategy Framework Directive. Estuar. Coast. Shelf Sci. 2011, 93, 117-131. [CrossRef]

29. Brockmann, U.; Topcu, D.H. Confidence rating for eutrophication assessments. Mar. Pollut. Bull. 2014, 82, 127-136. [CrossRef]

30. Tew-Kai, E.; Quilfen, V.; Cachera, M.; Noûs, C.B.M. Dynamic coastal-shelf seascapes to support Marine Policies using Operational Coastal Oceanography: The French example. J. Mar. Sci. Eng. 2020, in press.

31. Blauw, A.; Eleveld, M.; Prins, T.; Zijl, F.; Groenenboom, J.; Winter, G.; Kramer, L.; Troost, T.; Bartosova, A.; Johansson, J.; et al. Activity 1-Coherence in Assessment Framework of Chlorophyll A and Nutrients; European Sommision-DG Environment: Brussels, Belgium, 2019; p. 86.

32. Enserink, L.; Blauw, A.; Van der Zande, D. Summary Report EU Project Joint Monitoring Programme of the Eutrophication of the North Sea with Satellite Data (JMP EUNOSAT) (Ref: DG ENV/MSFD Second Cycle/2016); JMP EUNOSAT Program, 2019; 21p, Available online: https:/www.google.com.hk/url?sa=t\&rct=j\&q= \&esrc=s\&source=web\&cd=\&ved=2ahUKEwiu3uuPzfTqAhWPMd4KHe_sD14QFjAAegQIBRAB\&url= https\%3A\%2F\%2Fwww.informatiehuismarien.nl\%2Fpublish\%2Fpages\%2F163016\%2Fsummary_report. pdf\&usg=AOvVaw35IyoTZgddtk-OX_s4lvla (accessed on 24 July 2020).

33. Paerl, H.W.; Otten, T.G.; Kudela, R. Mitigating the Expansion of Harmful Algal Blooms across the Freshwater-to-Marine Continuum. Environ. Sci. Technol. 2018, 52, 5519-5529. [CrossRef]

34. Lefebvre, A.; Guiselin, N.; Barbet, F.; Artigas, F.L. Long-term hydrological and phytoplankton monitoring (1992-2007) of three potentially eutrophic systems in the eastern English Channel and the Southern Bight of the North Sea. ICES J. Mar. Sci. 2011, 68, 2029-2043. [CrossRef]

35. Prins, T.C.; Desmit, X.; Baretta-Bekker, J.G. Phytoplankton composition in Dutch coastal waters responds to changes in riverine nutrient loads. J. Sea Res. 2012, 73, 49-62. [CrossRef]

36. Ménesguen, A.; Desmit, X.; Dulière, V.; Lacroix, G.; Thouvenin, B.; Thieu, V.; Dussauze, M. How to avoid eutrophication in coastal seas? A new approach to derive river-specific combined nitrate and phosphate maximum concentrations. Sci. Total Environ. 2018, 628, 400-414. [CrossRef]

37. Desmit, X.; Thieu, V.; Billen, G.; Campuzano, F.; Dulière, V.; Garnier, J.; Lassaletta, L.; Ménesguen, A.; Neves, R.; Pinto, L.; et al. Reducing marine eutrophication may require a paradigmatic change. Sci. Total Environ. 2018, 635, 1444-1466. [CrossRef] [PubMed]

38. Lefebvre, A.; Poisson-Caillault, E. High resolution overview of phytoplankton spectral groups and hydrological conditions in the eastern English Channel using unsupervised clustering. Mar. Ecol. Prog. Ser. 2019, 608, 73-92. [CrossRef]

39. Rombouts, I.; Simon, N.; Aubert, A.; Cariou, T.; Feunteun, E.; Guérin, L.; Hoebeke, M.; McQuatters-Gollop, A.; Rigaut-Jalabert, F.; Artigas, L. Changes in marine phytoplankton diversity: Assessment under the Marine Strategy Framework Directive. Ecol. Indic. 2019, 102, 265-277. [CrossRef]

40. McQuatters-Gollop, A.; Mitchell, I.; Vina-Herbon, C.; Bedford, J.; Addison, P.F.E.; Lynam, C.P.; Geetha, P.N.; Vermeulan, E.A.; Smit, K.; Bayley, D.; et al. From Science to Evidence-How Biodiversity Indicators Can Be Used for Effective Marine Conservation Policy and Management. Front. Mar. Sci. 2019, 6, 1-16. [CrossRef]

41. Foden, J.; Devlin, M.J.; Mills, D.K.; Malcolm, S.J. Searching for undesirable disturbance: An application of the OSPAR eutrophication assessment method to marine waters of England and Wales. Biogeochemistry 2011, 106, 157-175. [CrossRef]

42. Lefebvre, A.; Dezécache, C. Trajectories of Changes in Phytoplankton Biomass, Phaeocystis globosa and Diatom (incl. Pseudo-nitzschia sp.) Abundances Related to Nutrient Pressures in the Eastern English Channel, Southern North Sea. J. Mar. Sci. Eng. 2020, 8, 401. [CrossRef]

43. Sigovini, M.; Keppel, E.; Tagliapietra, D. M-AMBI revisited: Looking inside a widely-used benthic index. Hydrobiologia 2013, 717, 41-50. [CrossRef]

44. Teixeira, H.; Berg, T.; Uusitalo, L.; Fürhaupter, K.; Heiskanen, A.S.; Mazik, K.; Lynam, C.P.; Neville, S.; Rodriguez, J.G.; Papadopoulou, N.; et al. A catalogue of marine biodiversity indicators. Front. Mar. Sci. 2016, 3. [CrossRef]

45. Benthoval Project. Available online: https://anr.fr/Project-ANR-13-BSV7-0006 (accessed on 24 July 2020).

46. Langhans, S.D.; Reichert, P.; Schuwirth, N. The method matters: A guide for indicator aggregation in ecological assessments. Ecol. Indic. 2014, 45, 494-507. [CrossRef] 
47. Borja, A.; Prins, T.C.; Simboura, N.; Andersen, J.H.; Berg, T.; Marques, J.C.; Neto, J.M.; Papadopoulou, N.; Reker, J.; Teixeira, H.; et al. Tales from a thousand and one ways to integrate marine ecosystem components when assessing the environmental status. Front. Mar. Sci. 2014, 1, 1-20. [CrossRef]

48. Borja, Á.; Rodríguez, J.G. Problems associated with the 'one-out, all-out' principle, when using multiple ecosystem components in assessing the ecological status of marine waters. Mar. Pollut. Bull. 2010, 60, 1143-1146. [CrossRef] [PubMed]

49. Perrot, T.; Rossi, N.; Ménesguen, A.; Dumas, F. Modelling green macroalgal blooms on the coasts of Brittany, France to enhance water quality management. J. Mar. Syst. 2014, 132, 38-53. [CrossRef]

50. Paumier, A.; Tatlian, T.; Réveillac, E.; Le Luherne, E.; Ballu, S.; Lepage, M.; Le Pape, O. Impacts of green tides on estuarine fish assemblages. Estuar. Coast. Shelf Sci. 2018, 213, 176-184. [CrossRef]

51. OSPAR Commission. Riverine Inputs and Direct Discharges to Convention Waters Case study on normalisation and trend analyses for OSPAR RID data Monitoring and Assessment Series. OSPAR Comm. 2017, 37. Available online: https://www.ospar.org/work-areas/hasec/chemicals/rid (accessed on 24 July 2020).

52. Grizzetti, B.; Pistocchi, A.; Liquete, C.; Udias, A.; Bouraoui, F.; Van De Bund, W. Human pressures and ecological status of European rivers. Sci. Rep. 2017, 7, 205. [CrossRef]

53. Dulière, V.; Gypens, N.; Lancelot, C.; Luyten, P.; Lacroix, G. Origin of nitrogen in the English Channel and Southern Bight of the North Sea ecosystems. Hydrobiologia 2019, 845, 13-33. [CrossRef]

54. Bartnicki Jerzy, B.A. Atmospheric Deposition of Nitrogen to the OSPAR Maritime Area in the period 1995-2014 Eutrophication. OSPAR Comm. 2017, EMEP/MSC-W, 107.

55. OSPAR Commission. OSPAR Science Agenda 2018 Update. OSPAR Comm. 2018, 20. Available online: https://www.ospar.org/work-areas/cross-cutting-issues/science-needs-agenda (accessed on 24 July 2020).

56. Andersen, J.H.; Carstensen, J.; Conley, D.J.; Dromph, K.; Fleming-Lehtinen, V.; Gustafsson, B.G.; Josefson, A.B.; Norkko, A.; Villnäs, A.; Murray, C. Long-term temporal and spatial trends in eutrophication status of the Baltic Sea. Biol. Rev. 2017, 92, 135-149. [CrossRef]

57. Dickey, T.D. Emerging ocean observations for interdisciplinary data assimilation systems. J. Mar. Syst. 2003, 40-41, 5-48. [CrossRef]

58. Muelbert, J.H.; Nidzieko, N.J.; Acosta, A.T.R.; Beaulieu, S.E.; Bernardino, A.F.; Boikova, E.; Bornman, T.G.; Cataletto, B.; Deneudt, K.; Eliason, E.; et al. ILTER-The International Long-Term Ecological Research Network as a Platform for Global Coastal and Ocean Observation. Front. Mar. Sci. 2019, 6, 1-14. [CrossRef] 